PSEUDO-HYPOPARATHYROIDISM

\title{
A DESCRIPTION OF THREE CASES AND A CRITICAL APPRAISAL OF EARLIER ACCOUNTS OF THE DISEASE
}

\author{
BY \\ M. E. MACGREGOR and T. P. WHITEHEAD \\ From the South Warwickshire Paediatric Unit
}

(RECEIVED FOR PUBLICATION APRIL 26, 1954)

The credit for recognizing that the term 'chronic idiopathic hypoparathyroidism' denotes at least two clinical entities belongs to Albright and his colleagues. In 1942 Albright, Burnett, Smith and Parson separated off a group of cases which they designated as 'pseudo-hypoparathyroidism', and they provided three illustrative case reports. In a second paper, in 1950, Elrick, Albright, Bartter, Forbes and Reeves defined this entity with greater precision, using data obtained from the study of 14 cases. These consisted of their own earlier three cases, and of four new ones of their own, as well as of those published by Sprague, Haines and Power (1945) and by Peterman and Garvey (1949). Five other unpublished cases which are referred to but of which the details are not provided in full make up the total of 14.

Pseudo-hypoparathyroid patients, according to these writers, are to be distinguished from other cases of chronic idiopathic tetany (and henceforward in this article this second group will be labelled 'spontaneous hypoparathyroidism') by the following characteristics.

(1) Clinically and biochemically they appear to conform to the pattern of parathyroid insufficiency. Drake, Albright, Bauer and Castleman (1939) regard a low serum calcium level with a high serum phosphorus level, unaccompanied by generalized bone disease, but with normal renal function and fat absorption, as the essentials of this diagnosis. Despite these findings, cases of pseudo-hypoparathyroidism show little or no response to parathyroid hormone either clinically or chemically, and some cases do not react in the normal way to A.T.10 (dihydrotachysterol) either (cf. Fig. 1).

(2) A typical physique is described, the components of which are a round face, shortness of stature, and a stocky or thick-set build.

(3) Changes in the shape of the metacarpal bones, less often of the metatarsals and phalanges as well, are frequently present. Metacarpals 1,4 and 5 are chiefly affected, and metacarpal 2 only rarely, whereas metatarsals 1 and 5 are the ones usually involved. These bones are abnormally short, often wider than normal, and sometimes their epiphyses invaginate the diaphyses because of inequality in rates of growth. In one case (that of Dr. J. Browne) premature closure of the epiphyses at the elbow, bowing of the legs and exostosis formation were present, and early closure of epiphyses was held to account for short stature in other cases. In short, an atypical chondrodystrophy is often associated with this syndrome.

(4) Subcutaneous calcification is present in many (10 of the 14 cases listed) and is usually associated with brachydactyly, inasmuch as only one case exhibited calcification without metacarpal changes. The calcification is generally in the neighbourhood of joints, especially of those in the hands and feet, but may be present in other sites. In some cases, as has been proved by biopsy, actual bone formation occurs.

(5) In three cases biopsies were carried out on the parathyroid glands. In two of these hyperplasia of the removed gland was found, and in the third a normal histology. (This case, however, had been treated for one month with A.T.10 before the biopsy was done.) From these findings and the observed insensitivity to parathyroid hormone the authors deduce that parathyroid hormone is being secreted by the glands, and that the metabolic error lies in the end-organ which is failing to respond to it. The original (1942) paper was sub-titled 'An Example of the Seabright Bantam Syndrome', thereby drawing an analogy to the Seabright Bantam cockerel which displays female plumage in spite of having androgenic hormone in the circulation, presumably because the end-organs fail to respond to the hormone. The beardless face of the American Indian, and the pitressin-resistant case of diabetes 

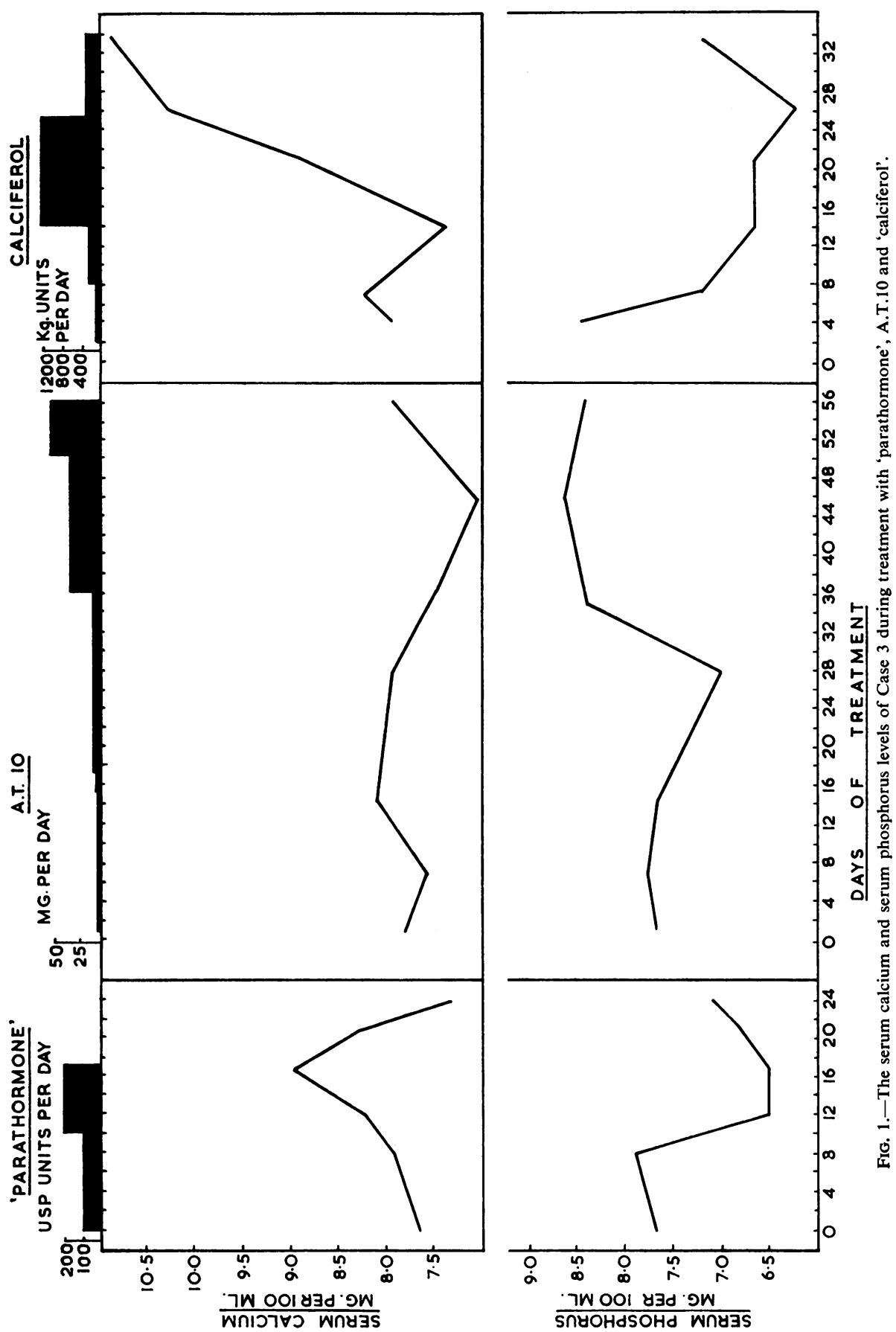
insipidus are other examples of end-organ unresponsiveness. However, as Alexander and Tucker (1949) point out, the comparison with the Seabright Bantam is unsatisfactory because Morgan's (1915) paper that describes the reactions of this bird reveals also that castration would restore the plumage to that of a normal male. Some more complex explanation than end-organ failure is therefore required. Perhaps for this reason Albright and his colleagues no longer designate pseudo-hypoparathyroidism as the Seabright Bantam syndrome after their first reference to the term (Albright et al., 1942). Nevertheless so colourful an association with a disease is not easily left behind, and it is still to be found in many textbook accounts of the condition.

Elrick et al. (1950) encountered the abnormality in two sets of identical twins, and in a mother and son, and suggested that there is an hereditary factor in the condition. They also drew attention to the low intelligence of several of their patients, presumed not to be a consequence of convulsions because one who was retarded had had no fits.

The authors conclude that the condition involves three disturbances, each of which is independent of the other two and can lead therefore to the following abnormalities, which may occur in any combination: (a) Disturbance of the parathyroid end-organ; (b) dyschondroplasia; (c) a propensity to form bone in subcutaneous tissues. When the second and third features are present without the first, tetany will of course be absent and serum calcium and phosphorus values normal. Such a case (tortuously labelled pseudo-pseudohypoparathyroidism!) was described by Albright, Forbes and Henneman (1952) in a Colombian girl who possessed all the physical features of pseudo-hypoparathyroidism except for hypocalcaemia, but interestingly enough is not related to have been mentally retarded. These authors very plausibly suggest that pseudo-hypoparathyroidism arises from the mutation of a gene which controls several traits, and offer as clinical parallels the syndromes of ovarian agenesis and of polyostotic fibrous dysplasia, in each of which an endocrine disorder is accompanied by several apparently unrelated abnormalities. It is now our intention to discuss in some detail the diagnostic criteria which have just been outlined.

\section{Insensitivity to Parathyroid Hormone}

It is of especial interest to observe by what standards the authors judge insensitivity to injected parathyroid hormone. Two of the cases in the 1942 paper were submitted to very large doses of parathyroid hormone (7,400 U.S.P. units in 12 days and 1,700 U.S.P. units in five days respectively) with no effect on serum calcium or phosphorus levels. Both these patients responded to A.T.10 with a rise of serum calcium, but the large dose of $25 \mathrm{mg}$. daily was necessary.

Ellsworth-Howard Test. In the other cases sensitivity to the hormone was assessed by means of the Ellsworth-Howard test (Ellsworth and Howard, 1934). This is a test which measures the power of an intravenous dose of parathyroid hormone to increase the renal clearance of phosphorus, and is simply performed by collecting hourly urine samples before and after an intravenous dose of 200 U.S.P. units (40 B.P.C. units) of parathyroid hormone, and comparing the subsequent urinary phosphorus excretion with the pre-injection levels. The originators of the test found that in normal subjects a two- or three-fold increase in phosphorus excretion was regularly obtained, often though not always accompanied by a diuresis, and that this rise occurred within the first three hours after the injection. When patients suffering from spontaneous or post-operative hypoparathyroidism were tested in this way an exaggerated response was obtained, the phosphorus clearance increasing by 10 or more times over the resting level. This enhanced response has been demonstrated in parathyroidectomize 6 experimental animals, and in human parathyroid deprivation due either to thyroidectomy or to spontaneous deficiency by a number of other workers (Albright and Ellsworth, 1929; Emerson, Walsh and Howard, 1941; Berezin and Stein, 1948; Medill, 1951).

Albright and his colleagues were able to confirm Ellsworth and Howard's results on normal individuals, but when the Ellsworth-Howard test was used on their cases of pseudo-hypoparathyroidism it was found that different results were obtained (Elrick et al., 1950). In three cases there was no response at all, although to one of these more than double the normal test dose of parathyroid hormone had been given. Repeated tests on the other two confirmed that an effect on phosphorus clearance was absent. In a fourth and fifth case, however, some response was obtained, though in the opinion of the authors there was a reduced sensitivity. 'Resistance to extract of parathyroid need not be complete', they remark, 'and the Ellsworth-Howard test alone may not be relied upon to distinguish between the two diseases,' namely pseudo- and spontaneous hypoparathyroidism. Writing at about the same time, however, Reifenstein (1950) stated that "patients with pseudo-hypoparathyroidism may exhibit a two-fold increase in urinary phosphate 
excretion, while normal subjects show a five- or six-fold increase, and patients with chronic or postoperative hypoparathyroidism show a ten-fold increase or greater'.

More recently, several published accounts reveal difficulties in reproducing the results of Ellsworth and Howard (1934) and Albright et al. (1942) in normal subjects. For example, Reynolds, Jacobson, Edmondson, Martin and Nelson (1952), in presenting a case of pseudo-hypoparathyroidism, admit that 'we have not obtained as marked a phosphorus diuresis as did the authors of the test, either in hypoparathyroid subjects or in normals, though two different brands and several batches of parathyroid hormone have been employed'. Dent (1953) performed the Ellsworth-Howard test on 15 normal people and found that there was hardly any increase in phosphorus excretion in the urine, in spite of the effectiveness of the parathyroid preparation in raising blood calcium levels in surgical hypoparathyroidism. He suggested that in modern preparations, which are assayed on their calcium-raising power, the phosphorus excretion effect is negligible. Milne (1951), however, although his results in normal subjects were much the same as Dent's, found that the hormone was able in the same dosage to produce a two- or three-fold increase in urinary phosphorus excretion in patients with spontaneous hypoparathyroidism. He concluded '... that the renal action of parathyroid hormone is maximal in hypoparathyroid states, but is already approaching its maximum in normals'.

Whatever the explanation, it is clear from these and from our own experience, which is described below, that the Ellsworth-Howard test does on many occasions fail to provoke phosphorus diuresis even in normal people. There is so far no great volume of evidence to contradict the impression that
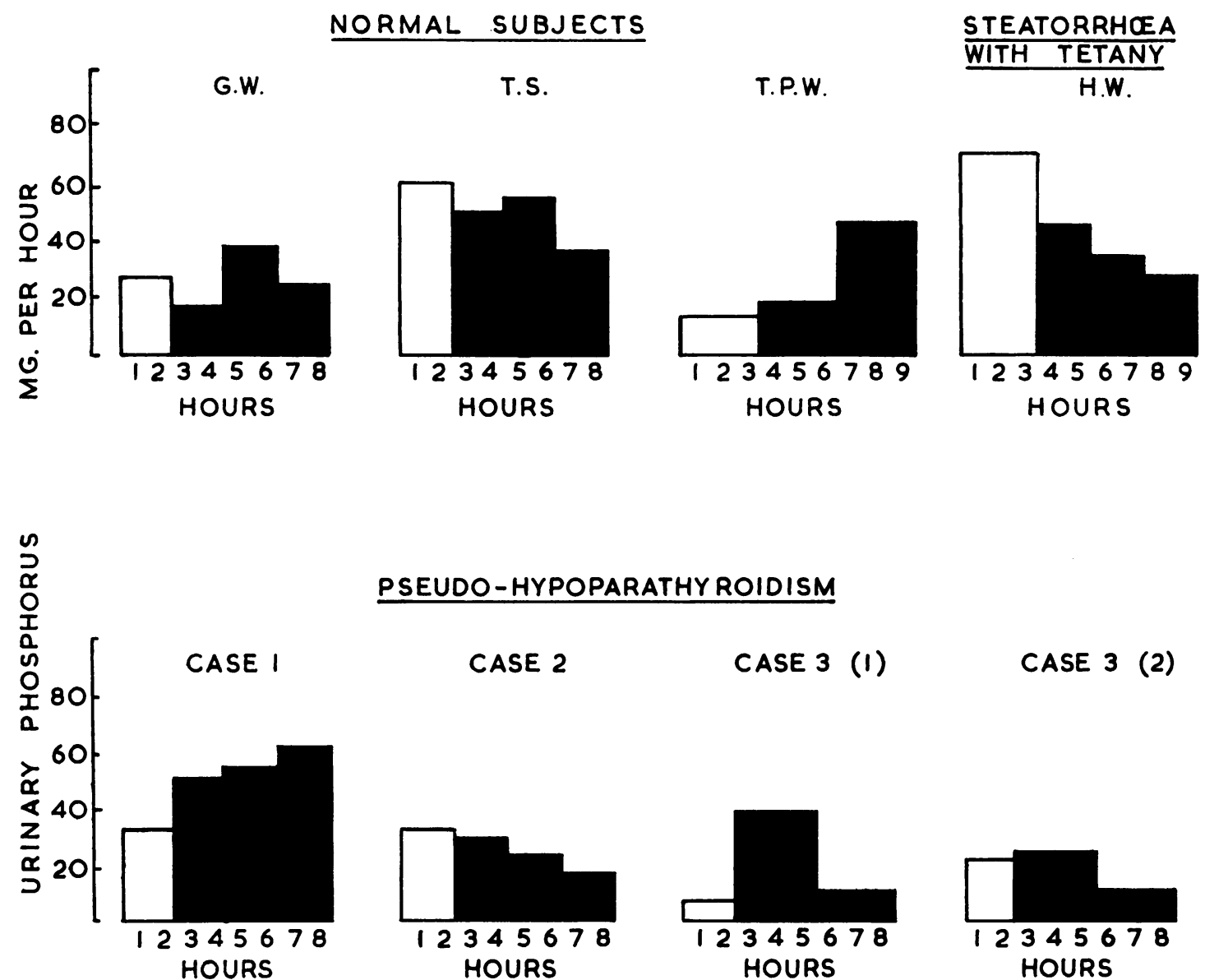

PSEUDO-HYPOPARATHYROIDISM

CASE 2

CASE 3 ( 1 )

CASE 3 (2)

FIG. 2.-The results of the Ellsworth-Howard tests. Urinary phosphorus excretion before and (shaded areas) after infection of 200 U.S.P. units of 'parathormone' intravenously. 
spontaneous and surgical hypoparathyroid patients always respond, but this test has been used in too few of the reported cases of spontaneous hypoparathyroidism for it to be looked upon as an invariable mode of reaction in those cases. Simpson (1953) reported a child with what is almost certainly spontaneous hypoparathyroidism, and in whom a negligible response to the Ellsworth-Howard test was obtained, while Dent (1953) in three cases of postthyroidectomy tetany found no response to an Ellsworth-Howard test in one, and a comparatively slight rise in urinary phosphorus in the other two.

Nevertheless the test has been much employed in the diagnosis of pseudo-hypoparathyroidism by writers after Elrick et al. (1950), and in some of these it is the main support of the diagnosis.

Trial of Intramuscular Parathyroid Hormone. A normal person responds to moderate doses of parathyroid hormone by a slight but definite rise in the serum calcium level (Aub, 1935; Dent, 1953). There is a great deal of individual variation in the readiness with which this response is evoked. Hypoparathyroid patients react to smaller doses with a greater rise in calcium level, but in some of these after weeks or months sensitivity lessens and progressively larger doses are necessary to achieve an effect, which may ultimately be lost altogether (Thorpe and Handley, 1929; Hunter, 1931; Aub, 1935; MacBryde, 1938; Pope and Aub, 1944). If a hypoparathyroid patient who has not received previous injections of parathyroid hormone does not produce a significant rise in serum calcium in response to a series of parathyroid hormone injections in large dosage, it is very remarkable, and separates such a case from the ordinary patient with parathyroid deficiency.

Besides pseudo-hypoparathyroidism, there are other possible reasons for such a lack of response. In the first place, after surgical removal of a parathyroid adenoma very severe tetany may ensue, which parathyroid hormone is powerless to control (Albright and Reifenstein, 1948).

Then, in certain cases of steatorrhoea with tetany parathyroid hormone seems to be ineffective, as in the published case of Lowe, Ellinger, Wright and Stauffer (1950). In another case of steatorrhoea with tetany, for details of which we are indebted to Dr. A. I. Cheyne and whose clinical features are summarized in the appendix, a similar failure to respond to the hormone was observed. In this instance not only did an Ellsworth-Howard test give a negative result, but after four days of 150 U.S.P. units 'parathormone' daily there was no significant change in his low serum calcium and high phos- phorus levels. Yet another case of steatorrhoea which failed to react to parathyroid hormone is known to us (Gillam and Morton, 1953).

Thirdly, Moehlig and Steinbach (1954) describe a patient with post-thyroidectomy tetany who became completely unresponsive to anti-tetanic drugs, including parathyroid hormone and dihydrotachysterol, while under treatment for another condition with cortisone. When cortisone was withdrawn, the tetany was again easily controlled.

Nevertheless, in spite of these limitations, it is a pity that this simple test has not been used more often (as it was by Albright et al., 1942; Cases 1 and 3 ) for the diagnosis of pseudo-hypoparathyroidism in preference to the less reliable Ellsworth-Howard test. It is true that although brisk responses to parathyroid hormone have been obtained in many cases of spontaneous hypoparathyroidism (Liu, 1928; Albright and Ellsworth, 1929; Thorpe and Handley, 1929; Leopold and Jonas, 1932; Cantarow, 1932; Goerner and Samuelsen, 1934; Humphreys, 1939; Cantarow, Stewart and Morgan, 1939; Franco, 1940; Lachmann, 1941; Sutphin, Albright and McCune, 1943; Leonard, 1946), one cannot safely declare that all would respond in this way, and there are many instances in the literature of cases that have not been tried with this treatment. With present knowledge, it seems fair to assert that if a patient with idiopathic hypoparathyroidism, who has never previously received parathyroid hormone, fails to achieve normal serum calcium values after a week of injections of a potent preparation of the hormone in a dose of at least 200 U.S.P. units (40 B.P.C. units) daily, then it is not a case of spontaneous hypoparathyroidism and, if fat absorption is normal, may be diagnosed as pseudo-hypoparathyroidism. Where, in reported cases, an inadequate response to parathyroid has been encountered, there is the possibility not only that the case may be a spontaneous one which is unaccountably inert, but also that the case is in reality one of pseudo-hypoparathyroidism (e.g. cases reported by Martin and Bourdillon, 1940; Jordan and Kelsall, 1951). Without collateral evidence of other kinds it is therefore difficult to distinguish with absolute certainty on the basis of parathyroid hormone therapy between the two clinical entities. This fact has been recognized by a number of continental authors, who have questioned the existence of pseudo-hypoparathyroidism, believing the anomalous hormonal response to be explicable in terms of variable potency of commercial products and the latitude of individual responses (Gsell, 1950; Schüpbach and Courvoisier, 1949; Martin, Guye, Babel and Courvoisier, 1952; Martin, 1953). 


\section{The Parathyroid Glands}

Little information has so far been collected about the appearance of the parathyroid glands in various states of hypoparathyroidism. Aplasia of the parathyroid glands is a very rare congenital malformation and is accompanied by other severe congenital defects incompatible with life (Drake et al., 1939; Selye, 1949). In all reports of absence of the parathyroid glands it is important to be sure that the cadaver was examined carefully from the mediastinum upward well into the neck, because of uncertainty of the anatomical position of these glands (Morgan, 1936). A few reports from the continental literature of patients of various ages in whom no parathyroid glands were found after death are cited by Lachmann (1941). Some of these had had tetany during life, but the detail with which the glands were searched for is not recorded. The same limitation applies to the instances, also cited by Lachmann, in which impetigo herpetiformis of Hebra, a recognized association with chronic tetany (Simpson, 1954), had been present during life and in which absence of the parathyroid glands was reported at necropsy.

Undoubted cases of spontaneous hypoparathyroidism which have been examined after death include a girl of 11 years who also had Addison's disease (Leonard, 1946). This patient had given a satisfactory therapeutic response to parathyroid hormone, and at necropsy no parathyroid tissue was to be found nor any adrenal cortex. Drake $e t$ al. (1939) reported a boy of 10 years of age, with spontaneous hypoparathyroidism, who died of staphylococcal septicaemia. Information is not provided about the response obtained during life to parathyroid hormone in this case. At necropsy the parathyroid glands were found to be of normal size and encapsulated, but under the microscope they were seen to consist, apart from a few scattered chief cells, entirely of fat. Cantarow $e t$ al. (1939) recount the case of a 12-year-old Irish girl who for six years was treated for her spontaneous tetany with daily or alternate daily injections of parathyroid extract, with benefit throughout. She died of an unexplained haemorrhagic illness and, in spite of a thorough examination from the mediastinum upwards, no parathyroid tissue was found at necropsy. In this case the effect of the long administration of hormone upon any glandular tissue present at the onset of the disease must be assessed. A most interesting report is that by Eaton, Camp and Love (1939). These authors report a man, 22 years of age (their Case 1), who had suffered from attacks of painful clenching of the hands and flexion of the elbows from the age of 8 , and in whom at 14 years generalized convulsions began. He also developed bilateral cataracts, lost his hair, suffered from increasing slowness and mental dulling, as well as from a chronic thrush infection of the mouth, and showed the characteristic symmetrical calcification of the basal ganglia associated with hypoparathyroidism. One observation of serum calcium at another hospital recorded a level of $11.9 \mathrm{mg}$. per $100 \mathrm{ml}$. This was not repeated, and Chvostek and Trousseau signs were not looked for. The patient had headaches and papilloedema, for which he had a craniotomy with negative findings. He died post-operatively of bronchopneumonia. Apart from a small $(12 \mathrm{~mm}$. diameter) cyst of the septum pellucidum, calcification was the only intracranial abnormality found at necropsy. Cystitis and oesophagitis were present. The parathyroid glands grossly and microscopically were normal. Despite the single serum calcium observation there are very strong grounds for considering this as a case of spontaneous hypoparathyroidism, and the interest of the parathyroid findings needs no emphasis therefore. Apart from the more obvious associations with chronic tetany that are present in this case history, thrush infection has been repeatedly described in hypoparathyroidism (Thorpe and Handley, 1929; Sutphin et al., 1943; Simpson, 1954) and headaches and papilloedema from the same cause that can simulate a cerebral tumour are well recognized (Barr, MacBryde and Sanders, 1938; Levy, 1947; Grant, 1953).

Necropsy reports are not available for published cases of pseudo-hypoparathyroidism, though one of Lachmann's (1941) cases (No. 58) was almost certainly suffering from this disease. It is disappointing to find the post-mortem findings dismissed with the remark that 'autopsy revealed no abnormalities of interest in this connection' (i.e. chronic tetany).

Against this background we must consider the experience of Albright and his colleagues (1942 and 1952) with parathyroid biopsy in three cases of pseudo-hypoparathyroidism. Only one of these exhibited ectopic calcification or brachydactyly, and the only published information about the response to parathyroid hormone in another is derived from the results of an Ellsworth-Howard test. In the case with hand changes and calcification a normal gland structure was detected; in the other two the glands were reported to show hyperplasia.

Parathyroid biopsy has not been attempted in other cases (with the exception of our Case 3, reported below, where the results were inconclusive), and the method does not lend itself for use as a diagnostic test. The American observations require 
to be extended. Quite apart from the gross structure of the gland, one must feel hesitation in interpreting histology in terms of function: hyperplasia need not imply hyperfunction nor normal histology a normally acting gland. A comparison with the diabetic pancreas is invited, and with the islet cell hyperplasia, which is often seen in haemolytic disease of the newborn, in which evidence of hyperinsulinism is wanting. Again, Eatnn's report of a normal-appearing gland in a probable case of spontaneous hypoparathyroidism challenges the validity of this test as a criterion of diagnosis, especially in view of the paucity of knowledge about the parathyroid gland in cases of spontaneous deficiency.

\section{Physique}

It is unwise to seek conclusive support for a diagnosis in body build. Roundness of the face, though real enough in many cases, is not a sufficiently objective quality to serve as a basis of distinction, and this has been remarked upon by Reynolds $e t$ al. (1952). Nor is shortness of stature confined to cases of pseudo-hypoparathyroidism. Lachmann (1941) records that many of his 22 Danish cases of chronic idiopathic tetany were very well below the average height, and it is unlikely that the pseudo-hypoparathyroid cases in the series are entirely responsible, inasmuch as they are so much rarer than cases of spontaneous hypoparathyroidism. There have been other reports of patients responsive to parathyroid hormone who have been of short stature (Emerson et al., 1941 (Case 1); McQuarrie, Hansen and Ziegler 1941). Stockiness is another rather subjective description; spontaneous cases seem to have been of any build, spare as were the cases of Brimblecombe (1949) and Salvesen (1930), or obese as were those of Mortell (1946), Lachmann (1941, Case No. 67) and Simpson (1952). Any effect of chronic hypocalcaemia on physique is likely to be more evident if the disease is present early, and the preponderance of dwarfism among pseudo-hypoparathyroid cases may be in part a reflection of the fact that in them the disorder is probably present from birth.

\section{Mental Condition}

In the histories of cases of chronic tetany it is difficult to decide whether mental infirmity, if present, developed before or after hypocalcaemia. One knows that a progressive dementia may set in after prolonged hypoparathyroidism of whatever cause (Simpson, 1952; Sugar, 1953), and so one must seek for cases of spontaneous hypoparathyroidism with reduced intelligence in childhood if a valid comparison is to be made, for many pseudo-hypoparathyroid cases are already recorded as defective at an early age. Examples of backwardness in young people with spontaneous hypoparathyroidism are to be found in the reports of Mortell (1946), Simpson (1952), Eaton and Haines (1939), Eaton et al. (1939) and Barr et al. (1938). Some of these were, perhaps, suffering from pseudohypoparathyroidism. Mental capacity, nevertheless, seems an unsound means of diagnostic differentiation.

\section{Family History}

Spontaneous hypoparathyroidism very seldom develops in more than one member of a family, and we have found in the literature only one example, namely the remarkable Italian family reported by Sutphin et al. (1943) in which three siblings suffered from the disease. This well-documented instance, however, eliminates family history as a perfect criterion for distinguishing between spontaneous and pseudo-hypoparathyroidism.

In addition to the three examples of family incidence in cases labelled as pseudo-hypoparathyroidism by Elrick et al. (1950), none of which for reasons stated elsewhere in this paper are included in the group of 27 cases which we have analysed below, there is some further evidence of a family tendency to the disorder. Thus, Lachmann (1941) reports an interesting family of five in which two sisters and a brother were affected, and probably also another sister (Cases 57, 58 and 59 of Lachmann). The remaining brother appeared to be unaffected. Selye (1949) reports a mother and child with the disease, Uhlemann (1950) found the disease in two sisters, and the sister of Azerad, Gatha and Raverdy's (1953) patient was also probably affected. All of these cases showed changes in the metacarpal bones, and we accept them as proven cases of pseudo-hypoparathyroidism.

There are objections, then, as we have seen, to accepting conventional methods of measuring the response to parathyroid hormone, or the results of parathyroid biopsy, or a special physical or mental constitution as diagnostic of pseudo-hypoparathyroidism. To the first the objection is the difficulty in interpretation, to the second that knowledge is inadequate, and to the third that overlap with findings in spontaneous hypoparathyroidism exists.

\section{Bone Changes and Subcutaneous Calcification}

No such criticism can be levelled at the remaining two criteria put forward by Elrick et al. (1950), namely chondrodystrophy mainly involving metacarpal and metatarsal bones and ectopic calcification. Wherever either of these have been observed 
the case has conformed in other ways to the type described by Albright, and no instance of a satisfactory therapeutic reaction to parathyroid hormone is to be found among such cases. That reported by Cantor and Scott (1942) in whom there were 'several minute areas of calcification in the soft tissues of the neck' may be disregarded, as it was otherwise typical of spontaneous hypoparathroidism, and the calcium may well have been the relic of healed tuberculous lymph nodes. Other than this there are no reports of soft tissue calcification in parathyroid-hormone-sensitive cases. Intracranial calcification, common to all forms of chronic tetany (Camp, 1947; Siglin, Eaton, Camp and Haines, 1947), is of course excepted.

In collecting cases of pseudo-hypoparathyroidism from the literature, therefore, we have looked upon chronic tetany, together with brachydactyly and the characteristic metacarpal or metatarsal radiological changes, or with ectopic calcification or bone formation, as indisputable proof of the condition. Twenty-three cases of this kind have been discovered. This is not the total number, as it does not include the five unpublished cases alluded to by Elrick et al. (1950), about which only a few details are available, but otherwise the literature up to the end of 1953 has been fairly fully covered. In addition we present three new cases of our own, and one unpublished case is included for details of which we are indebted to Dr. W. W. Payne (1953). The clinical features of these 27 cases have been collectively studied, and some observations about them follow. Only 14 of them were published as cases of pseudo-hypoparathyroidism (Albright et al., 1942, two cases; Sprague et al., 1945, one case; Peterman and Garvey, 1949, one case; Selye, 1949, two cases; Schüpbach and Courvoisier, 1949, one case; Elrick et al., 1950, one case; Alexander and Tucker, 1949, one case; Bakwin, Gorman and Ziegra, 1950, one case; Bishop and de Mowbray, 1951, one case; Reynolds et al., 1952, one case; Bille, 1952, one case; and Azerad et al., 1953, one case). The other cases were those of Himsworth and Maizels (1940), reported as congenital thyroid and parathyroid deficiency; Lachmann's (1941) three cases, Nos. 57, 58 and 59, reported as idiopathic hypoparathyroidism; of Richardson (1946), reported as chronic idiopathic hypoparathyroidism; of Scott and Temple (1949), reported as osteoma cutis; of Gsell (1950), reported as chronic idiopathic tetany; and of Uhlemann (1950), two cases, reported as familial idiopathic tetany.

Brief summaries of these cases are to be found in the appendix to this paper.

Details of our own cases now follow.
Case 1. R.V.B., aged 23 (date of birth February 14, 1930), an English male, was the only child of an unmarried woman living in poor surroundings. Details of the father are lacking, but the mother is said to be normal. The patient is said to have been normal until 6 years old, when he entered school and was discovered to be backward. In 1937, aged 7, he was admitted to a London hospital because of obesity and 'attacks'. Positive signs then were obesity, mental dullness and undescended testicles. The serum calcium level was $7.6 \mathrm{mg}$. per $100 \mathrm{ml}$. and serum phosphorus $3.7 \mathrm{mg}$. per $100 \mathrm{ml}$. The diagnosis was idiopathic tetany. The patient was readmitted in the following year, and diagnosed as calcinosis, for plaques of calcium had appeared on the face, hands, abdomen and ears. An ear tophus consisted of calcium phosphate with organic protein. He made little progress at school. On leaving he worked for a short time as a manual labourer, but in 1946 he was certified as a mental defective and admitted to a suitable hospital in Norfolk. Since admission there he had had two episodes which might have been convulsions or else attacks of tetany. During a period at home on licence he committed a sexual assault on a 4-year-old girl. He was admitted to our care for observation on November $25,1953$.

He was childish, amiable and lacking in iniative, and spoke slowly in a monotone. His face was expressionless, round, and with few associated movements. His physique was muscular but not obese (Fig. 3).

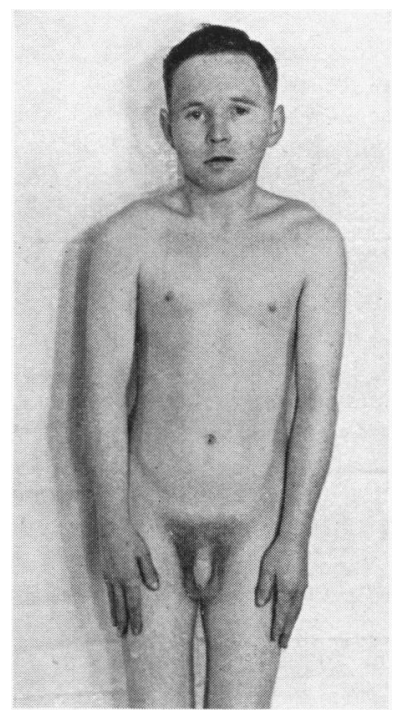

FIG. 3.-Case 1. He walked bent a little forward with a shuffling gait. His height was $5 \mathrm{ft}$., weight 77 lb., span 58 in., symphysis to soles $30 \frac{1}{2}$ in. and symphysis to vertex $29 \frac{1}{2}$ in. The hands showed unusually short thumbs. The feet showed shortening of toes 1, 4 and 5 (Fig. 4).

Acuity of vision was fair. Coarse radial opacities were visible in the periphery of the lenses. The ocular fundi were normal.

The nails were normal on the hands, thickened on the feet.

A number of small sessile papillomata were seen in the upper part of the body. Numerous flat reddishbrown naevi were scattered about the body. A biopsy of one of these showed a simple naevus pigmentosus of intradermal type. Patches of symmetrical eczema on both hands were said to have been present for one year. Numerous subcutaneous nodules of calcium hardness, the largest an irregular plaque over the left zygoma, were 
felt. Palpable nodules were also found at the back of the neck, on the dorsa of the arms and on the hands and feet. The Chvostek sign was positive, and the Trousseau sign negative.

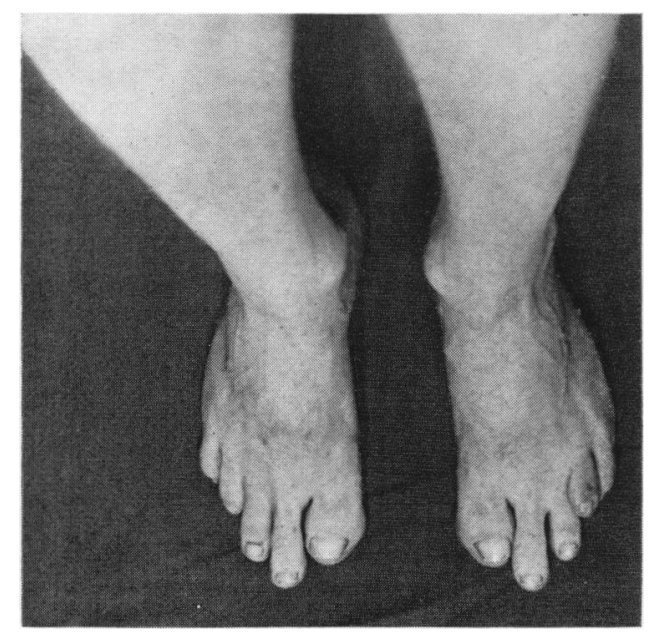

Fig. 4.-Feet of Case 1.

He was edentulous, and the hair was normal. Blood pressure was normal.

InVESTIGATIONS. Serum calcium level was $7.6 \mathrm{mg}$. per $100 \mathrm{ml}$., serum phosphorus $5.7 \mathrm{mg}$. per $100 \mathrm{ml}$., serum alkaline phosphatase $7 \cdot 3 \mathrm{~K}$-A units per $100 \mathrm{ml}$. The Sulkowitch test was negative, otherwise no urinary abnormality, and the urinary 17-ketosteroid excretion $6 \cdot 2 \mathrm{mg}$. a day. The serum sodium, potassium, chloride, urea and alkali reserve were normal. An electrocardiogram was normal.

X-RAY Examination. This showed general osteoporosis of the skeleton with loose texture, and extensive calcification of the soft tissues, much of it subcutaneous, especially marked in the hands and feet and around most of the large joints.

The spine showed slight osteoporotic flattening and concavity, with calcification of short anterior ligaments in the mid-dorsal region.

Extensive fairly symmetrical calcification in the region of the basal ganglia, several unerupted molar teeth in the upper and lower jaws, soft-tissue calcium plaques below the occipital protuberance and left fronto-temporal region were all seen in the skull plates.

Right humerus varus with osteo-arthritis and capsular calcification was seen.

Very marked osteoporosis of the pelvis was observed. There were small subcutaneous calcium deposits around the knees, and an exostosis of the right upper fibula.

The first and right fifth metacarpals of the hands were strikingly shortened with very loose texture in the fifth metacarpals. Subcutaneous calcification was extensive (Fig. 5).
The first metatarsals and phalanges of the feet were short and thick, and the left fourth and right fourth and fifth metatarsals were strikingly shortened. Extensive subcutaneous calcification was seen.

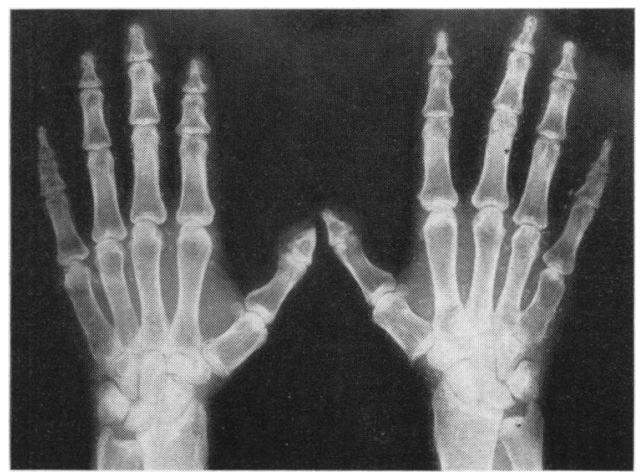

Fig. 5.-Case 1, radiograph of hands.

Electro-encephalogram. The record was moderately abnormal with evidence of failure of maturation, but none of any tendency to seizures.

Mental State. His intelligence quotient was 52 on the Terman-Merrill Form L.

Ellsworth-Howard Test. See Fig. 2 and the subsequent discussion.

Response to Parathyroid HoRmone. 'Parathormone' (Lilly) was injected intramuscularly for seven days in a single dose of 200 U.S.P. units per day. The Chvostek sign was present throughout. The serum calcium level before was $7.6 \mathrm{mg}$. per $100 \mathrm{ml}$. and after $7.5 \mathrm{mg}$. per $100 \mathrm{ml}$; serum phosphorus level before, $5.7 \mathrm{mg}$. per $100 \mathrm{ml}$. and after, $4.9 \mathrm{mg}$. per $100 \mathrm{ml}$.

Case 2. V.C.E., aged 24 (date of birth November 16, 1929), was a Welsh girl. Comparatively little is known of her early history, as her mother died when she was 3 years old, and she was brought up in an orphanage. She had an unexplained illness in infancy, after which she developed fits. Because of backwardness and timidity she did not go to school until very late. She was certified as a mental defective in 1947, at the age of 17. Since then she has been in a mental defective hospital in Glamorgan. She was admitted to our unit for investigation on January 11, 1954.

In the hospital for mental defectives she had shown herself as a pleasant, smiling person, quiet and affectionate, but timid and easily affected by nervous influences. Since admission she had been subject to recurrent vomiting attacks which lasted for several days and seemed to be excited by nervous causes, during which manifest tetany had been observed. Once hemitetany was seen, but never epilepsy. Menses were normal.

On examination the patient was small, not obese, with a round and plump face. The legs were obviously short, 
especially proximally. Her nutrition was good (Fig. 6). Her height was $4 \mathrm{ft}$. 5 in., weight $78 \mathrm{lb}$., span 54 in., symphysis to soles 25 in. and symphysis to vertex 28 in. Chvostek's sign was positive and Trousseau's sign

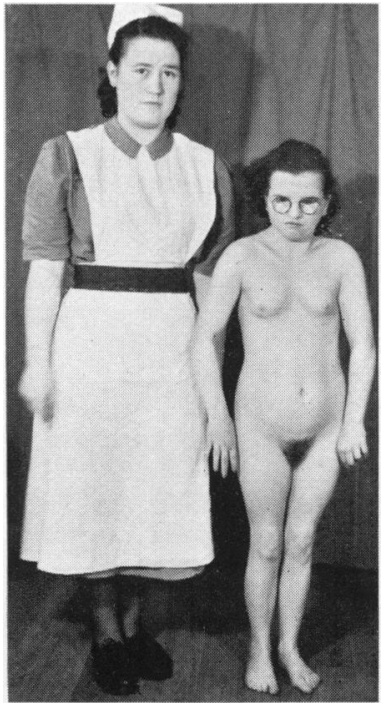

FIG. 6.-Case 2, V.C.E., with control of same age. negative. The skin, hair and teeth were normal.

The patient wore thick glasses for myopia. Several streaks of opacity were seen in the crystalline lenses. Fundi were normal.

The finger nails were transversely ridged and bitten, but were probably within normal limits. The toenails were thickened and dystrophic. She had short, thick fingers and thumbs, especially the fourth and fifth fingers (Fig 7).

The feet were normal.

No subcutaneous nodules were palpable. The blood pressure was $105 / 75 \mathrm{~mm}$. Hg.

No other abnormalities were recorded.

INVESTIGATIONS. The serum calcium level was $8.0 \mathrm{mg}$. per $100 \mathrm{ml}$., serum phosphorus $5.8 \mathrm{mg}$. per $100 \mathrm{ml}$., and serum alkaline phosphatase $6 \cdot 7 \mathrm{~K}-\mathrm{A}$ units per $100 \mathrm{ml}$. No abnormalities were found in the urine. The Sulkowitch test was faintly positive. The output of 17-ketosteroids in 24-hour urine was $0.5 \mathrm{mg}$. per diem. This is well below the average for the patient's age. The radio-active iodine uptake was normal.

The serum sodium, potassium, urea and alkaline reserve were normal.

X-RAY EXAmination. The only bone abnormalities were in the hands. The fourth and fifth metacarpals were markedly shortened in both hands, and the first

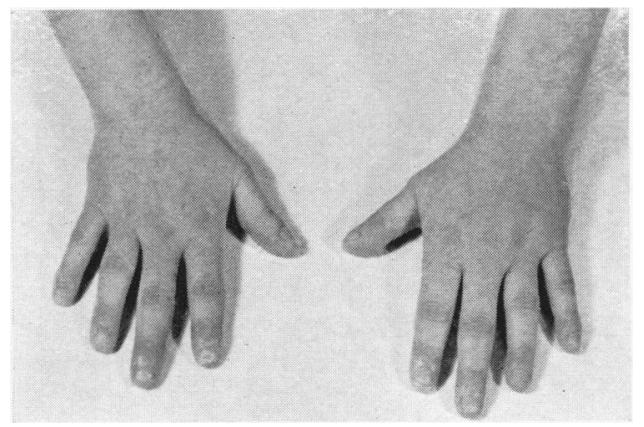

Fig. 7.-Hands of Case 2. metacarpal also on the left (Fig. 8). Cranial bones, spine and bones of the extremities were otherwise normal. No obvious intracranial calcification was seen.

The chest was normal.

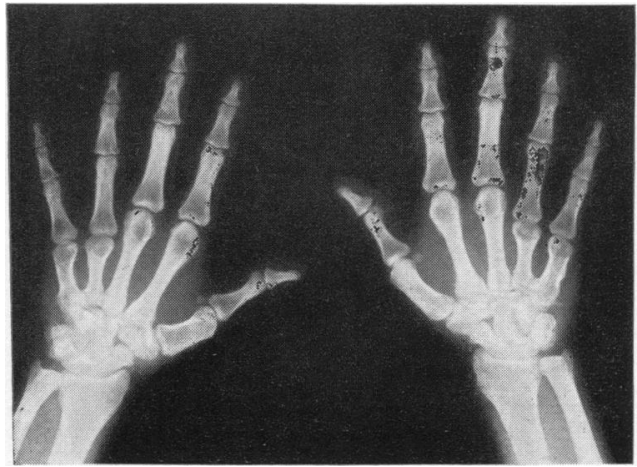

Fig. 8.-Case 2, radiograph of hands.

Widespread subcutaneous calcification, mostly of a finely mottled type, was seen in the hands, wrists, feet especially around the heels, and also in the suboccipital region, as well as at the back of the root of the neck.

Mental State. Her intelligence quotient was 68 and her mental age about 10 .

Ellsworth-Howard Test. See Fig. 2 and subsequent discussion.

Respionse to Parathyroid Hormone. 'Parathormone' (Lilly) was injected intramuscularly for nine days in a dosage of 400 U.S.P. units daily, in two divided doses. She received therefore a total of $18 \mathrm{ml}$. $(3,600$ U.S.P. units) in the nine-day period. The serum calcium level before starting injections was $8.0 \mathrm{mg}$. per $100 \mathrm{ml}$., and serum phosphorus $5.8 \mathrm{mg}$. per $100 \mathrm{ml}$. The serum calcium at the end of the injections was $8.9 \mathrm{mg}$. per $100 \mathrm{ml}$., and serum phosphorus $5.0 \mathrm{mg}$. per $100 \mathrm{ml}$.

Case 3. T.F., aged 13 (date of birth April 13, 1940), an English boy, was delivered normally at home. He was breast fed with no difficulty. He sat up at 6 months, walked at 13 months, and cut his first teeth at 8 months. He started to have fits at $4 \frac{1}{2}$ years, which were controlled for a year with phenobarbitone, but then recurred more frequently in spite of treatment. He first went to school at 6 years old. He did not seem to learn, and after three years at school could neither read nor write. Because of backwardness he was tried at a special (for the educationally subnormal) school when aged 10 , but fits demanded his return home, where he had been for a year before certification and admission to a mental deficiency hospital at the age of 12 .

He had always been fat and a 'big eater'. Stiffness of the hands had been noticed at times for two years.

He had had measles, 'bronchial asthma' from about 
6 months old, particularly before and after fits, and an electric burn of the hand when aged 5 .

Two younger siblings were both healthy and of normal physique. The parents were well and unrelated. No family history of fits or nervous illness was given.
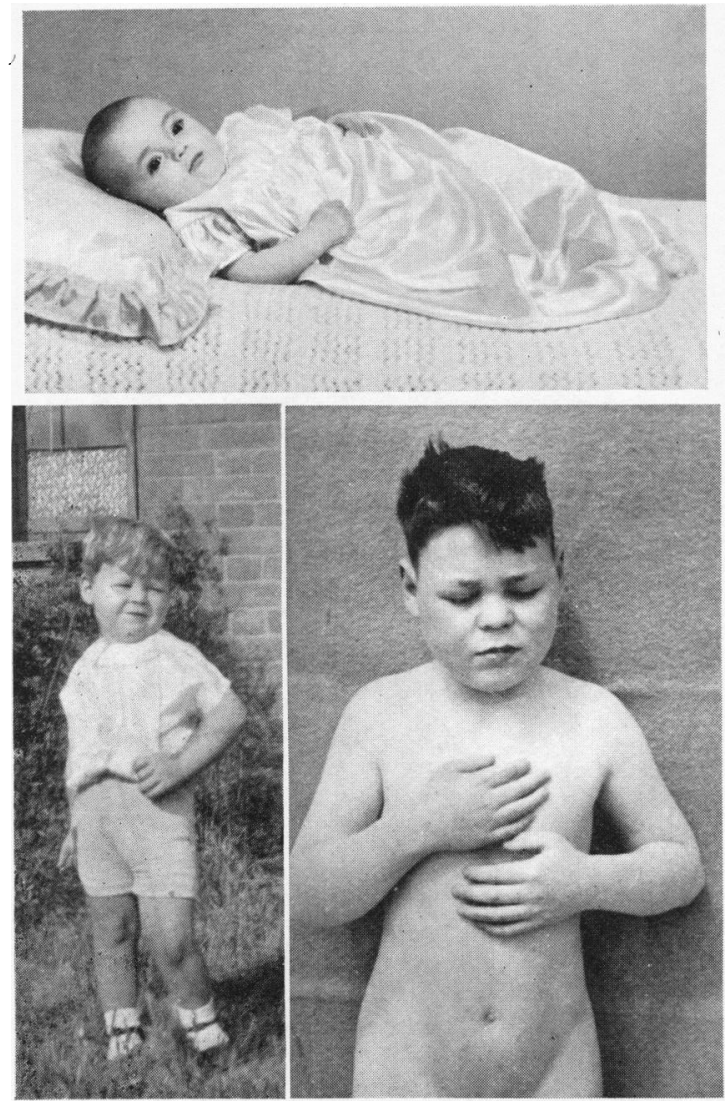

Fig. 9.-Case 3, T.F., aged 3 months, 5 years, and 14 years.

In the hospital for mental defectives he had major convulsions at approximately monthly intervals, in spite of regular phenobarbitone, 1 gr. daily. His mental age was 6. For six months he had been becoming very fat, gaining from $83 \mathrm{lb}$. in February, 1952, to $100 \mathrm{lb}$. in December, 1952. He was then put on thyroid, 1 gr. daily. In March, 1953, painful carpo-pedal spasms developed, and in the succeeding weeks he had several convulsions in rapid succession. Thyroid was discontinued and he was given calcium by mouth. As symptoms continued he was transferred to our unit for investigation.

On admission he was a fat, placid, friendly boy with a round face and a slow mind (Fig. 9). His weight was 95 lb., height $4 \mathrm{ft}$. 8 in., span 55 in., pubis to vertex $26 \frac{1}{2}$ in., and pubis to soles $29 \frac{1}{2}$ in. The Chvostek and Trousseau signs were positive.

All his teeth had erupted and appeared normal. The nails, skin and hair were normal.
The thumbs appeared short and did not extend more than half-way along the first phalanx of the index finger when outstretched.

Fine pouvdery opacities in the crystalline lenses were seen on slit lamp examination. The ocular fundi were normal.

His blood pressure was $150 / 120 \mathrm{~mm}$. $\mathrm{Hg}$ in both arms. No other abnormal physical signs were seen.

INVESTIGATIONS. The serum calcium level was $5.1 \mathrm{mg}$. per $100 \mathrm{ml}$, serum phosphorus $8.7 \mathrm{mg}$. per $100 \mathrm{ml}$., and serum alkaline phosphatase $25 \mathrm{~K}-\mathrm{A}$ units per $100 \mathrm{ml}$. on admission.

On two occasions in May the urine showed a trace of albumin, but subsequently no albumin or other abnormality was detected. The urinary Sulkowitch reaction was negative. The total calcium in a 24-hour urine specimen was $25 \mathrm{mg}$. per $100 \mathrm{ml}$. The urinary 17-ketosteroid excretion was $4.9 \mathrm{mg}$. per diem, a normal result.

The serum sodium, potassium, chloride, urea and alkali reserves were normal. The total serum protein and albumin:globulin ratio were also normal.

The total fat excretion in faeces over a three-day period was $12 \mathrm{~g}$.

Renal Function Tests. The Van Slyke urea clearance test, and the patient's power to concentrate and dilute his urine were both satisfactory.

Electrocardiogram. This was normal, except for prolongation of QTc to $0.47 \mathrm{sec}$.

Cerebrospinal Fluid Examination. Pressure was $120 \mathrm{~mm}$. $\mathrm{H}_{2} \mathrm{O}$, cells fewer than 2 per c.mm., protein $60 \mathrm{mg}$. per $100 \mathrm{ml}$.

X-RAY Examination. Bone age and bone density were normal, without bone deformities. There was stippled symmetrical calcification in the basal ganglia, and very delicate calcification in the subcutaneous tissues on the inner aspect of both feet. A single spot was also seen on the radial side of the third metacarpal head but none elsewhere.

Mental Testing. He was cooperative and a good test was possible. On the Terman-Merrill M (Revision) Scale his mental age was 6 years and 4 months (I.Q. 48). This compares with a test on the L Scales 18 months before, when his mental age was 6 years (I.Q. 51).

Electro-encephalogram. The resting record was dysrhythmic. Focal seizure activity (petit mal variant type) occurred in the right frontal lead, and was increased by overbreathing. The record was indicative of epilepsy.

Professor P. Cloake, of the Queen Elizabeth Hospital, Birmingham, compared this tracing with one taken by him three years before. He comments, 'The earlier tracing (1950) shows marked, diffuse abnormality, very suggestive of epilepsy. Your record shows less activity at $8 \mathrm{c} / \mathrm{s}$ than ours, but shows the $2-3 \mathrm{c} / \mathrm{s}$ activity upon which our report was largely based. Neither record 
shows the marked fast activity and the dominant 6-7 c/s activity in the frontal areas which is said to be characteristic of hypoparathyroidism (Gotta and Odoriz, 1948).'

BloOD-PRESSURE. On admission, and for two weeks afterwards, his blood-pressure was elevated, ranging from $130 / 110$ to $160 / 130 \mathrm{~mm}$. $\mathrm{Hg}$. It then gradually fell to $130 / 80 \mathrm{~mm}$. $\mathrm{Hg}$, but remained subject to fluctuation throughout his hospital stay. There was a suggestion that his blood pressure would rise for a few days before and after a fit, but a rise and fall occurred sometimes independently of these, and seemed also independent of serum calcium variations and of clinical tetany or latent tetany. Although Albright states that hypertension is not an uncommon finding in pseudo-hypoparathyroidism (Albright et al., 1952), study of published cases does not bear this out.

Ellsworth-Howard Test. The patient's response to intravenous parathyroid hormone was tested on two occasions and the results are set out in Fig. 2, and discussed below.

Parathyroid Biopsy. On October 14, 1953, an exploratory operation on the neck was performed by Mr. G. C. Taylor. The right lateral lobe of the thyroid gland was freed and dislocated towards the mid-line, exposing the whole of its anterior and posterior surfaces. No evidence of parathyroid tissue was found during a careful and extensive dissection. Fragments of tissue removed and examined histologically consisted of thymus and thyroid tissue only.

Progress in Hospital. For a few days after admission he was mentally confused and rather drowsy, and was subject to frequent generalized convulsions. Chvostek and Trousseau signs were very active, and carpo-pedal spasms occurred spontaneously on a few occasions. During this period it was observed that an intravenous injection of $10 \mathrm{ml}$. of a $10 \%$ calcium gluconate solution made no difference to his Chvostek reaction.

From the time that a small addition of calcium chloride was made to his diet, latent tetany varied in intensity, the Chvostek sign being negative during the greater part of the time. Convulsions also became less frequent and occurred about once monthly. No significant decrease in his fits was noted when he was given continuous phenobarbitone. His mind became quite clear, though slow, and he mixed happily with the other children, and took an intelligent interest in ward affairs. Coincidentally there was a rise in serum calcium from the initial low level of $5 \cdot 1 \mathrm{mg}$. per $100 \mathrm{ml}$. to between 7 and $8 \mathrm{mg}$. per $100 \mathrm{ml}$., which level with fluctuations commented on below, was maintained through the greater part of his hospital stay.

Treatment. Table 1 illustrates the dietary additions and drugs that he received, and records beside them the fluctuations in his serum calcium and phosphorus levels. By the use of a low phosphorus diet, and again later by adding aluminium hydroxide to the diet (Albright, Burnett, Parson and Sulkowitch, 1941), it was hoped to increase the serum calcium by selectively favouring its absorption from the intestine (Shelling and Goodman, 1934; Anderson and Lyall, 1939). No such effect was observed in this case, although the effectiveness of the aluminium hydroxide regime in reducing phosphorus absorption was proved by a considerable sustained drop in urinary phosphorus excretion. Urinary phosphorus in mg. per hour was estimated daily on urine specimens collected between 6.0 p.m. and 6 a.m. approximately. For the period September 17 to October 2, during which he was on a normal diet, the averaged nightly output of phosphorus was $29.8 \mathrm{mg}$. per hour. From October 3 to November 9, while receiving aluminium hydroxide, this figure had dropped to $12.4 \mathrm{mg}$. per hour.

Effect of ParathyroId Hormone. From September 2 to 10 he was given daily 100 U.S.P. units 'parathormone' (Lilly) by intramuscular injection, and from September 10 to 17200 U.S.P. units daily. The variations of serum calcium and phosphorus in this period are shown graphically in Fig. 1. During the period September 3 to 17 the nightly urinary excretion of phosphorus averaged $30.2 \mathrm{mg}$. per hour, which will be seen to differ hardly at all from the period when he was on normal diet without additions. A rise in serum calcium and a drop in serum phosphorus which were co-extensive with the 'parathormone' dosage period were observed. Although fluctuations had previously been observed to occur spontaneously within even wider limits, the serum calcium had never previously changed consistently in the same direction for so long a time, and this result, coupled with an immediate fall when the hormone was stopped, offers presumptive evidence of an effect, albeit sluggish.

EFFect of Dihydrotachysterol (A.T.10). This was given in gradually rising dosage for eight weeks. No effect at all was demonstrated on serum electrolytes, nor did the patient's urinary Sulkowitch reaction become more than transiently positive, in spite of the enormous. final dosage of $50 \mathrm{mg}$. daily. A natural curiosity to discover how high a dosage he would tolerate had to be curbed by the expense of the drug, which in the final period was costing $£ 3$ a day. The manufacturers, Messrs. Bayer and Co., report that the batch of A.T.10 used had been checked and found to be biologically active. Absolute resistance to dihydrotachysterol does not seem to have been observed in other cases of pseudohypoparathyroidism, although tolerance to increased dosage has been commented upon by Albright et al. (1942), and some other authors. The majority of published cases seem to have reacted normally to the drug. Apparently resistance to A.T.10 is not confined to pseudo-hypoparathyroidism, for Blohm, Wurl, Gillespie and Escamilla (1953) describe inadequate response in a case of post-thyroidectomy tetany, while Moehlig and Steinbach (1954), found a similar case while simultaneously receiving cortisone to be totally unresponsive to A.T.10 and other drugs.

EFfect of Calciferol. For the treatment of spontaneous hypoparathyroidism it is generally agreed that calciferol and A.T.10 are equally effective (McLean, 
TABLE 1

DIET AND DRUG REGIMES IN CASE 3 (T.F.) WITH SERUM CALCIUM AND PHOSPHORUS LEVELS

\begin{tabular}{|c|c|c|c|c|c|}
\hline Date & Regimes & & Date & (mg. per $100 \mathrm{ml})$. & $\stackrel{\text { P }}{(\mathrm{mg} . \text { per } 100 \mathrm{ml} .)}$ \\
\hline 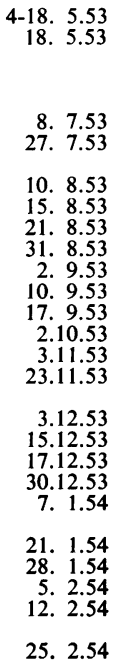 & 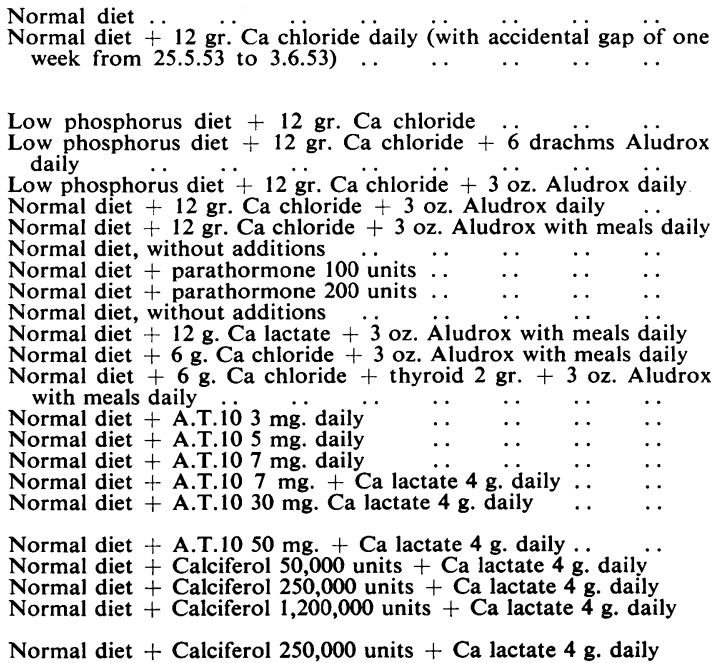 & 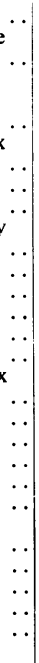 & $\begin{array}{r}\text { 5. } 5.53 \\
15.5 .53 \\
5.6 .53 \\
18.6 .53 \\
16.7 .53 \\
\text { 7. } 8.53 \\
19.8 .53 \\
21.8 .53 \\
24.8 .53 \\
1.9 .53 \\
8.9 .53 \\
17.9 .53 \\
30.9 .53 \\
2.11 .53 \\
7.11 .53 \\
1.12 .53 \\
8.12 .53 \\
15.12 .53 \\
29.12 .53 \\
5.1 .54 \\
14.1 .54 \\
26.1 .54 \\
4.2 .54 \\
11.2 .54 \\
18.2 .54 \\
23.2 .54 \\
2.3 .54\end{array}$ & $\begin{array}{r}5 \cdot 1 \\
5 \cdot 8 \\
7 \cdot 8 \\
8 \cdot 4 \\
8 \cdot 2 \\
8 \cdot 1 \\
7 \cdot 7 \\
10 \cdot 3 \\
8 \cdot 8 \\
6 \cdot 9 \\
7 \cdot 9 \\
9 \cdot 0 \\
8 \cdot 2 \\
7 \cdot 8 \\
8 \cdot 1 \\
7 \cdot 8 \\
7 \cdot 6 \\
8 \cdot 1 \\
7 \cdot 9 \\
7 \cdot 5 \\
7 \cdot 0 \\
7 \cdot 9 \\
8 \cdot 2 \\
7 \cdot 3 \\
8 \cdot 9 \\
10 \cdot 3 \\
10 \cdot 9\end{array}$ & $\begin{array}{l}8 \cdot 2 \\
7 \cdot 5 \\
5 \cdot 3 \\
4 \cdot 4 \\
8 \cdot 0 \\
7 \cdot 9 \\
6 \cdot 5 \\
7 \cdot 6 \\
6 \cdot 4 \\
6 \cdot 7 \\
7 \cdot 7 \\
7 \cdot 8 \\
7 \cdot 7 \\
7 \cdot 0 \\
8 \cdot 4 \\
8 \cdot 6 \\
8 \cdot 4 \\
7 \cdot 2 \\
7 \cdot 4 \\
6 \cdot 7 \\
6 \cdot 8 \\
7 \cdot 7\end{array}$ \\
\hline
\end{tabular}

1941); the former is usually preferred because it is less expensive. Calciferol seems to be also successful in the treatment of pseudo-hypoparathyroidism. This patient is no exception, though large doses were necessary to raise his serum calcium to a normal level (Table 1), and his serum phosphorus was relatively less affected.

EXPERIENCE WITH THE Ellsworth-Howard TeST. Hourly collections of urines, as suggested by Ellsworth and Howard in their original description of the test, are often difficult with patients of low intelligence. We have had to modify the test to two-hourly collections, and in one case three-hourly collections of urine, before and after giving 200 U.S.P. units 'parathormone' (Lilly) intravenously. For six hours before the injection and throughout the test only water was given by mouth. The results of the test on each of the cases of pseudohypoparathyroidism are shown in Fig. 2. Two tests were performed on Case 3 . It will be seen that of the four tests, two showed some increase in urinary phosphorus, one a definite decrease and another showed a very slight increase. There was a decrease in urinary phosphorus in the case of steatorrhoea with tetany following intravenous 'parathormone'.

Fig. 2 also records our inability to show any immediate urinary phosphorus response to 'parathormone' injections in normal subjects, although in one normal subject there was an increase between the third and sixth hours after injection. Our experience is similar to that of Milne (1951) and Dent (1953). The results indicate that the Ellsworth-Howard test is of no value in differentiating between the 'normal response' and the so-called

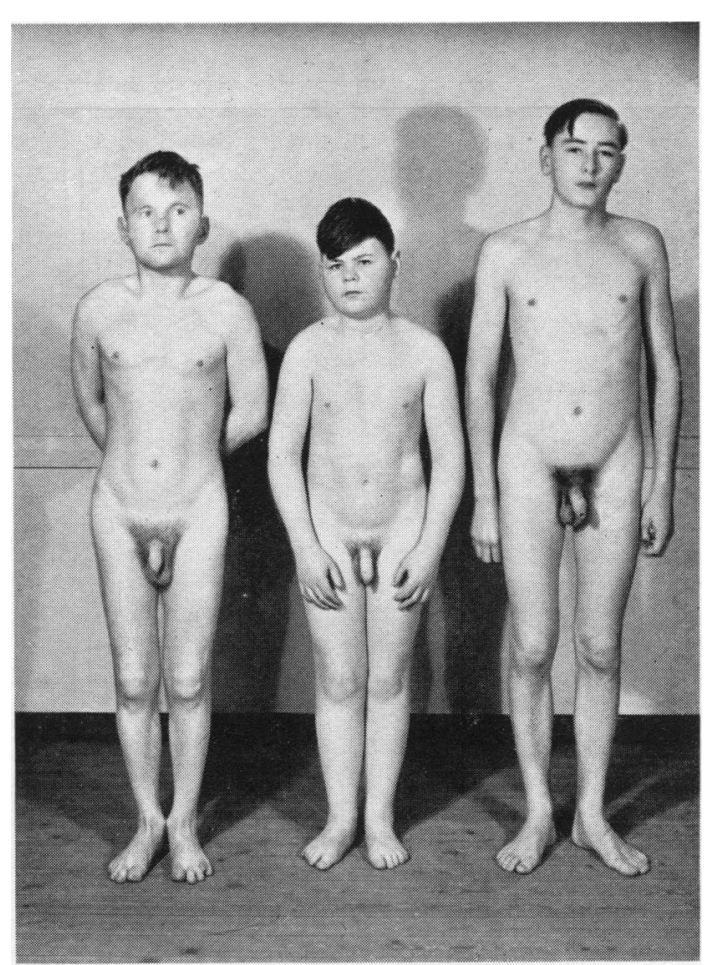

FIG. 8.-Cases 1 and 2, with a normal 15-year-old boy. 
'resistant response' of pseudo-hypoparathyroidism. We have not had the opportunity to test the hormone preparation on cases of spontaneous hypoparathyroidism. Milne (1951) found in such cases a two- to three-fold increase in urinary phosphorus and Dent (1953) reported similar results in two cases of surgical hypoparathyroidism and no response in a third. In such cases Albright has found a tenfold increase.

It appears therefore to be established that the urinaryphosphorus-raising power of the 'parathormone' available in Britain is very much less than that present in the hormone preparation which Albright used. The manufacturers (Eli Lilly Co.) inform us, however, that the product available in Britain is the same as that sold in America.

\section{Analysis of Foregoing 27 Cases of Chronic Tetany with Bone Changes or Ectopic Calcification}

Age and Sex Incidence. In this group of 27 cases, 15 are female and 12 male. The youngest in the series is 7 years (Payne, 1953), and the oldest 49 years (Alexander and Tucker, 1949).

Race. Nine are American (one a Negro), four English, three Danish, three German, one Welsh, one Swiss, one Swedish, one French, one Italian and one a Russian Jew.

Presenting Symptom. In five tetany, or symptoms referable to muscular hyper-excitability (laryngospasm, wheezing, stridor), were first noticed. In 11 convulsions or 'attacks' brought the patient to medical notice. Two had no symptoms at all. Calcified skin lesions were the first symptoms in two, and two others presented with backwardness. 'Poor nerves' and 'excessive sleepiness' were the first symptoms of another two. In two cases there is no record on this point.

General Symptomatology. It is interesting that in spite of the presumably congenital nature of the malady, symptoms referable to hypocalcaemia were not experienced under the age of 2 , and in most cases frank tetany was not apparent until the middle years of childhood or later, if indeed it was ever manifested. Convulsions, which occurred at some time in 16 cases, generally began in childhood and frequently before any sign of tetany had been noticed. Where the condition was recognized in infancy it was the development of calcific nodules in the skin that enabled this. Backwardness is almost the rule among them, and is reported in 19 of the 20 whose mentality is commented upon. One case (Alexander and Tucker, 1949) is reported to have had normal intelligence. The retardation does not seem to be very gross, though several have found their way into hospitals for the mentally defective. The lowest reported intelligence quotient was 50 (our Case 1). Many authors comment on the friendly, docile personalities of these patients, so-called 'smiling imbeciles'. Other factors besides basic personality may contribute to this slowness and passivity. In the first place a number of cases have been suspected of hypothyroidism. Himsworth and Maizels' (1940) case had a basal metabolic rate of $25 \%$ and was treated as a cretin. Lachmann's (1941) Case 59 was said to have a myxoedematous appearance, with a basal metabolic rate of $-16 \%$. Peterman and Garvey's (1949) case was diagnosed as hypothyroidism originally. Our Case 3 showed an unexpectedly low uptake of radio-active iodine, suggesting thyroid dysfunction, whereas Case 2, like that of Azerad et al. (1953), showed a normal uptake. It does not appear that the co-existing thyroid deficiency is a regular feature of the syndrome, though possibly present in some cases.

Secondly, several of the older patients showed signs of Parkinsonism, such as an immobile face, a lack of associated movements and a propulsive gait. One also had tremor. This feature is undoubtedly connected with the calcification of the basal ganglia that is visible in radiographs of these patients, and has also been seen in spontaneous hypoparathyroidism (Eaton and Haines, 1939). In four of this series these symptoms were commented upon (Alexander and Tucker, 1949; Gsell, 1950; Reynolds et al., 1952; and in our Case 1).

Concerning sexual functions, several have shown delay in acquiring secondary sex characters. In three women menstruation started respectively at 17 , 18 and 22 years of age. In one of these the periods were scanty and irregular, and in a fourth case also irregular menses were noted. One male had a delayed puberty (aged 22 years), and another aged $2 \frac{1}{2}$ had undescended testicles. Alexander and Tucker's (1949) patient, on the other hand, was married and had two normal children, while the presence of a strong sexual instinct may be deduced from the behaviour of our Case 1 , who at the age of 21 years sexually assaulted a child of 4 years. It is noteworthy that Greene and Swanson (1941) describe eroticism as a feature of the mental disturbance of some cases of hypoparathyroidism. A reduced 17-ketosteroid output was observed in one of our cases, but normal values have been obtained in others.

Physique. A round face was specifically mentioned in 16 cases. Twenty out of 24 in whom height is recorded were dwarfed, that is to say were of less than the minimum height recorded for their ages in standard tables, or were less than $5 \mathrm{ft}$. in 
height if adult. Four were within normal limits for height, but these were aged $3 \frac{1}{4}, 2 \frac{1}{2}, 9 \frac{1}{4}$ and 13 years when they were measured, and may have shown retardation of growth later. One other is described as 'stocky', but measurements are not given. Dwarfism was disproportionate in five cases, the limbs being preponderantly shortened. Twelve cases were described as obese; none were thin or underweight. Nine of them were recorded as having been fat from infancy, and at least two reached extraordinary weights when babies. Thus, Alexander and Tucker's (1949) case weighed $45 \mathrm{lb}$. when 9 months old, while Scott and Temple's (1949) case is said to have weighed $32 \mathrm{lb}$. at 5 months, and $67 \mathrm{lb}$. at 14 months! It is perhaps worth recording that three of this group of 27 cases are said to have had red hair.

Skeletal Changes. The alterations in the radiological outlines of certain bones that Albright and his colleagues observed have already been recounted. In reviewing the 27 cases that we have collected, we have tabulated skeletal changes as follows:

\begin{tabular}{lllllr} 
Total number showing bone & \multicolumn{2}{l}{ changes } & $\ldots$ & 20 \\
Metacarpal changes & $\ldots$ & $\ldots$ & $\ldots$ & $\ldots$ & 20 \\
Metatarsal changes & $\ldots$ & $\ldots$ & $\ldots$ & $\ldots$ & 6 \\
Phalangeal changes & $\ldots$ & $\ldots$ & $\ldots$ & $\ldots$ & 7 \\
Exostoses $\quad \ldots$ & $\ldots$ & $\ldots$ & $\ldots$ & $\ldots$ & 3 \\
Bowing of bones & $\ldots$ & $\ldots$ & $\ldots$ & $\ldots$ & 4 \\
Early closure of epiphyses & $\ldots$ & $\ldots$ & $\ldots$ & 5 \\
Generalized osteoporosis & $\ldots$ & $\ldots$ & $\ldots$ & 6 \\
Generalized osteosclerosis & $\ldots$ & $\ldots$ & $\ldots$ & 2
\end{tabular}

Metacarpal and metatarsal changes follow exactly the pattern outlined by Albright, and the second and third bones were seldom involved. Changes in metatarsals or phalanges were never present unless there were changes in the metacarpals too. Whereas changes in bone density are seldom encountered in spontaneous hypoparathyroidism, variations in both directions are recorded in this group, and osteoporosis was striking in the case of Reynolds et al. (1952) and in our Case 1.

Elrick et al. (1950) drew attention to another disease state in which brachydactyly is conjoined with ectopic calcification, namely progressive myositis ossificans. We may refer to two other abnormalities which in their osseous manifestations bear an even closer resemblance to pseudo-hypoparathyroidism. These are familial brachydactyly (Brailsford, 1945), and chondroectodermal dysplasia (Ellis and van Creveld, 1940). In the former condition there are metacarpal and metatarsal changes identical with those we are studying, and sometimes these are accompanied by exostosis formation. In chondro-ectodermal dysplasia, the bone disorder, in spite of many resemblances to pseudo-hypoparathyroidism, shows some distinctive features, but the clinical likeness is made closer by coexisting changes in teeth, nails and hair, and occasionally also by localized soft tissue calcification in the former condition.

Bone dystrophy was absent in seven patients in this series, all of whom of course showed subcutaneous calcification. In another eight bone changes were present without a report of calcification in the tissues, though it was not always specifically looked for.

Subcutaneous Calcification. This was observed in 19 patients, 12 of whom had bone changes as well. Most often it took the form of scattered small fragments in the limbs, especially in the hands and feet; larger palpable nodules and plaques were found in some cases, in any situation. In several biopsy demonstrated actual bone formation in these. How early these lumps appeared in two cases has already been mentioned. They are usually painless, though some tenderness was present over a large plaque in the upper part of the cheek of our Case 1.

Other Findings. Cataracts were noticed in 12 patients, and symmetrical calcification of the basal ganglia (Eaton and Haines, 1939) in ten. Although Reynolds et al. (1952) commented that the incidence of intracranial calcification seemed unusually high in pseudo-hypoparathyroidism (and this might be expected if it is looked upon as a secondary change, and the disease is congenital), nevertheless this figure represents but a third of the total. In truth, the numbers are probably greater, for several are not recorded to have had radiographs of the skull taken.

Ectodermal defect was commonest in the teeth, but in contrast to reports of spontaneous hypoparathyroidism, changes in hair or nails are seldom commented upon. Two of this series developed exfoliative dermatitis, and one died as a result.

Serum calcium and phosphorus levels were generally within the usual range for hypoparathyroidism (calcium 4 to $8 \mathrm{mg}$. per $100 \mathrm{ml}$., phosphorus 4 to $13 \mathrm{mg}$. per $100 \mathrm{ml}$.), though a serum calcium reading of $10.8 \mathrm{mg}$. per $100 \mathrm{ml}$. on Selye's (1949) Case 2 should be noted. Three cases, all children, had slightly elevated serum alkaline phosphatase levels (15 Bodansky units, 24 and 25 King-Armstrong units per $100 \mathrm{ml}$. respectively).

In these 27 cases parathyroid hormone, whenever tried, elicited no more than a very slight increase in serum calcium, in whatever dosage it was used. We believe that the conjunction of chronic tetany with these specific radiological findings will allow a patient to be labelled as pseudo-hypopara- 
thyroidism, and by this diagnosis it is implied that the serum calcium response to parathyroid hormone will prove to be greatly reduced or absent, in striking contrast with the responses obtained in surgical or spontaneous hypoparathyroidism.

To this nucleus of pseudo-hypoparathyroidism, two other cases from the literature can be added on the strength of a clearly demonstrated deficiency in response to parathyroid hormone after a trial in satisfactory dosage, even though in these cases metacarpal changes and calcifications are wanting. Brief summaries of these two cases (Albright et al., 1942, Case 2; and Elrick et al., 1950, Case 1) now follow.

Albright et al. (1942), Case 2. American girl aged 12 years, always overweight and mentally dull. Tetany from 3 years of age. Positive Chvostek reaction. Serum calcium $8.9 \mathrm{mg}$. per $100 \mathrm{ml}$., phosphorus $6.3 \mathrm{mg}$. per $100 \mathrm{ml}$. Increased radiological density of bones. Negative Ellsworth-Howard test. Several injections of 500 U.S.P. units of parathyroid hormone had no effect on serum levels of calcium and phosphorus. Response to A.T.10 in dosage of 10 to $15 \mathrm{mg}$. daily.

Elrick et al. (1950), Case 1. American man aged 27 years. Fits for 15 years, tetany for one year. Round faced, short (height $4 \mathrm{ft}$. 10 in.). Mentally retarded (I.Q. 69). Latent tetany, cataracts, calcification of basal ganglia; no teeth. Ellsworth-Howard test negative. Serum calcium 7.0 per $100 \mathrm{ml}$, phosphorus $12 \mathrm{mg}$. per $100 \mathrm{ml}$. No response to five days of parathyroid hormone in a dosage of 500 U.S.P. units daily, but ready response to A.T.10. Parathyroid biopsy showed hyperplasia of gland.

In our opinion the foregoing account incorporates the only cases of pseudo-hypoparathyroidism in the literature which can be accepted unequivocally on the published evidence. They number 25 , and they are briefly summarized in the appendix, where some details of an unpublished child with the same condition are also to be found.

Two cases reported under this label by Albright and his colleagues have been rejected.

Elrick et al. (1950), Case 3. American woman aged 34 years. She, and an identical twin sister, had had tetany all their lives, especially at the menses. In both hypertension had developed at 33 years of age. Height $4 \mathrm{ft} .3$ in., round face. Latent tetany, calcification of basal ganglia. Blood pressure 190/115 mm. Hg. Ellsworth-Howard test 'decreased sensitivity to parathyroid hormone'. Parathyroid biopsy showed hyperplasia of the gland.

This case rests for diagnosis on physique and response to the Ellsworth-Howard test, neither of which can be regarded as conclusive. The positive family history is further evidence for pseudo- hypoparathyroidism but again is not decisive (see above). At present the biopsy finding, though of great interest, is not of much evidential value.

Elrick et al. (1950), Case 4. American girl aged 9 years. Tetany since 4 years, and asthma. Height 4 ft. 8 in. Latent tetany. Ellsworth-Howard test 'decreased sensitivity'.

As published, this case relies for diagnosis on the Ellsworth-Howard test, and so cannot be accepted.

In the literature there are a number of other cases which offer some grounds for thinking that they may be cases of pseudo-hypoparathyroidism, though proof is wanting. These have been reported under various labels, and brief summaries are appended below.

Kirklin and Childrey (1936). American girl of 19 years. Tetany from 12 years of age. Dull mentality, Cataracts. Short, stubby fingers. Serum calcium $5.2 \mathrm{mg}$. per $100 \mathrm{ml}$., phosphorus $8.5 \mathrm{mg}$. per $100 \mathrm{ml}$. Hypothyroid appearance. Basal metabolic rate $15 \%$.

Reported as 'spontaneous parathyroid tetany'.

Martin and Bourdillon (1940). Italian male of 39 years. Tetany since 5 years old. 'Mediocre' intellectual development; worked as a tailor. Short, bald. Latent tetany. Dense bones in radiographs. Serum calcium $6.7 \mathrm{mg}$. per $100 \mathrm{ml}$., phosphorus $4.8 \mathrm{mg}$. per $100 \mathrm{ml}$. No clinical response to several injections of 100 U.S.P. units parathyroid hormone.

Reported as 'chronic idiopathic tetany'.

Lachmann (1941), Case No. 71. Danish woman aged 37 years. Winter tetany since 15 years old. Cataracts, psoriasis. Delicately built with short extremities, height $4 \mathrm{ft} .5$ in. Mental development below average. Very small breasts and scanty pubic hair. Diffuse thyroid enlargement. Treated with parathyroid hormone and calcium but no effect on symptoms or serum calcium. Serum calcium $6.8 \mathrm{mg}$. per $100 \mathrm{ml}$. A brief trial of small doses of A.T.10 had no effect.

Case presented as 'idiopathic hypoparathyroidism'. Details of parathyroid dosage wanting.

Moehlig and Gerische (1950). Armenian male of 19 years. Fits since 12 years of age. Thickset, heavy (121 lb.) and round faced, height $4 \mathrm{ft} .9$ in., with short extremities. Latent tetany. Short hands. Unerupted and dystrophic teeth. Coarse trabeculation of certain bones in radiographs. Serum calcium $4.7 \mathrm{mg}$. per $100 \mathrm{ml}$. No response to Ellsworth-Howard test. Reacted well to A.T.10.

This case was reported as 'pseudo-hypoparathyroidism' but depends on the Ellsworth-Howard test for diagnosis.

Jordan and Kelsall (1951). English boy of 16 years. Onset of tetany aged 9 years. Convulsions. Mentally alert; short and sturdy. Height $4 \mathrm{ft} .9$ in. Dystrophic teeth. Cataracts. Sclerosis of bones. Intracranial 
calcification. Serum calcium $6.3 \mathrm{mg}$. per $100 \mathrm{ml}$, phosphorus $9 \cdot 1 \mathrm{mg}$. per $100 \mathrm{ml}$. Very sluggish response of serum calcium and urinary phosphorus excretion after 200 U.S.P. units parathyroid hormone.

Reported as 'idiopathic hypoparathyroidism'.

Berardinelli (1951). Brazilian girl of European ancestry, aged 16 years. Epilepsy and diabetes insipidus from age 4 years. Height $4 \mathrm{ft}$. 8 in. Obese, anxious, highly intelligent. Latent tetany. Intracranial calcification. Serum values of calcium and phosphorus not obtained. Treated with 100 U.S.P. units parathyroid hormone daily for 40 days without clinical response. Response to A.T.10 was immediate (abolition of anxiety and positive Sulkowitch reaction in urine).

Presented as 'pseudo-hypoparathyroidism and diabetes insipidus'. Besides the latter disorder, the high intelligence and lack of serum electrolyte values make the diagnosis difficult to substantiate.

Wise and Hart (1952), Case 3. Puerto Rican woman aged 24 years. Convulsions from age 1 year. Mentally backward, I.Q. 57. Dwarfed but well proportioned. Height $4 \mathrm{ft} .2$ in. Dystrophic teeth. Cataracts. Cerebral calcification. Serum calcium $3.8 \mathrm{mg}$. per $100 \mathrm{ml}$., phosphorus $10 \mathrm{mg}$. per $100 \mathrm{ml}$. Gave birth to an unaffected infant after a normal pregnancy, aged 24 years. Ellsworth-Howard test negative. Brisk response to A.T.10.

The authors suggest that this is a case of pseudohypoparathyroidism but do not regard this as proved without a biopsy of a parathyroid gland.

One further case was reported as pseudo-hypoparathyroidism by Lowe et al. (1950). There are a number of anomalous features in this patient, an American boy of 4 years whose symptoms date from early infancy, and in whom tetany was associated with prolonged steatorrhoea. The child's physique and mentality were not those of other cases of pseudo-hypoparathyroidism, and the case is best regarded as one of steatorrhoea with tetany. Some $x$-ray changes in the metacarpals were noted, but these are uncharacteristic, and the diagnosis rests very insecurely on the results of the EllsworthHoward test.

\section{Incidence of the Disease}

It should now be clear that the symptomatology of these cases is very varied. They may come to notice in childhood or later with epilepsy, with mental backwardness, with dwarfism, with obesity, with cataracts or with skin lesions, and with or without tetany. Although only one case has so far been published as pseudo-hypoparathyroidism in the British literature (Bishop and de Mowbray, 1951), reasons have already been given for thinking that the cases of Himsworth and Maizels (1940) and of Richardson (1946) are also examples.
We discovered accidentally one of our cases (Case 3) in a mental deficiency institution, and so it seemed advisable to seek for other cases hidden in such hospitals. A postal enquiry to some 100 mental deficiency hospitals in Great Britain subsequently brought two other cases (our Cases 1 and 2) to light. Both Lachmann (1941) and Bakwin et al. (1950) suggest that collections of mental defectives probably include unrecognized cases of hypoparathyroidism, and the latter authors examined the hands of 1,000 epileptics in a colony for evidence of pseudohypoparathyroid deformity, with negative results.

We searched for other cases of hypoparathyroidism by serum calcium or phosphorus estimations on a group of unselected epileptic children attending hospital as out-patients, on a group of children with cataracts in a school for the partially sighted, and on a group of 150 mentally defective epileptic children in an institution. No further examples were found.

The literature concerning osteoma of the skin, reviewed by Vero, Machacek and Bartlett (1945), does not appear to contain other recognizable cases of this disease.

Some idea of the rarity of pseudo-hypoparathyroidism may be derived from Wise and Hart's (1952) figures. In a large hospital in the United States with 62,000 admissions yearly only one possible case was detected in a 10-year survey. However it may be that some cases do not reach general hospitals at all.

\section{Discussion}

What is the reason for the discrepancy between the results obtained by Albright and other American workers concerning the effect of parathyroid hormone on the excretion of urinary phosphorus, and those of Dent (1953), Milne (1951) and ourselves?

Commercial parathyroid extract is assayed biologically on its power to raise the serum calcium level of dogs. This method of assay would be satisfactory if the physiological action of the hormone was that envisaged by Dent (1953), namely that it increases calcium and phosphorus in the serum by its stimulating action on osteoclasts. This would result in a raised calcium:phosphorus product, which returns to normal via enhanced phosphorus excretion. Accordingly, the increase in urinary phosphorus is dependent upon the raised serum calcium level. On the other hand, were Albright's hypothesis of parathyroid action the right one, namely that the hormone directly stimulates the kidney to excrete phosphate, and that the rise in serum calcium is secondary to a consequent fall 
in serum phosphorus level, then this would imply that the many batches of 'parathormone' recently used in Britain were of very low potency or even inactive.

There is, however, ample evidence that the hormone as received in Britain has serum calciumraising power. Dent (1953) showed that although he could not produce hyperphosphaturia in normal subjects they did display a slight but definite rise in serum calcium, and this has also been our experience. Moreover our patient 3 showed a rise in serum calcium whilst being given high doses of the drug over a long period. In cases of spontaneous or post-operative hypoparathyroidism appearing in the British literature the extract has been shown to be completely satisfactory in serum calcium-raising power (Dent, 1953).

The only satisfactory explanation of these results is to be found in recent work on parathyroid extracts. This has provided evidence that there are two active hormones present in the extracts. L'Heureux, Tepperman and Wilhelmi (1947) have identified two proteins in parathyroid extract by electrophoresis in the Tiselius apparatus. Stewart and Bowen (1952) have reported that preparations of parathyroid hormone after treatment with formaldehyde lose their power to raise the serum calcium level of dogs whilst still being able to increase the excretion of urinary phosphorus. Davies and Gordon (1953) have been successful in isolating and separating two hormones from parathyroid glands, one being responsible for calciumraising power and the other hormone increasing urinary phosphorus.

The explanation of the difference in the response to parathormone found by Albright and the response found by more recent British investigations, therefore, may be that over a period of years changes have been made in the processes of manufacture of the extract, which have not affected its serum calcium-raising power but have altered its power to increase urinary phosphorus.

The difference of response between normal and pseudo-hypoparathyroid subjects is one of the bases of Albright's 'target-organ defect' hypothesis. This difference we have been unable to confirm. Furthermore, if the parathyroid gland excretes two hormones, and we feel there is very strong evidence for this, then there would have to be two simultaneous 'target-organ defects' in pseudo-hypoparathyroidism.

Again, the defect, if it exists, must be incomplete at one end-organ, because parathyroid extract is sometimes able to provoke a rise in serum calcium in pseudo-hypoparathyroidism. For the above reasons it seems likely to us that some other ex- planation than end-organ insensitivity is at the root of the puzzling responses of these cases, and particularly because we have encountered precisely similar aberrations in response in some cases of steatorrhoea with tetany.

\section{Summary}

The clinical features of pseudo-hypoparathyroidism, first defined and named by Albright and his colleagues, are described, examined, and contrasted with those of spontaneous hypoparathyroidism.

Using only the diagnostic criteria that are considered to be valid, 25 published accounts of pseudo-hypoparathyroidism have been collected.

Three new case reports are added to these, and some details are provided of another unpublished case. A group of 27 cases is then surveyed, and some other unproven cases possibly of the same type are described.

Certain difficulties were encountered in trying to reproduce the responses to parathyroid hormone that other workers have obtained in normal and pseudo-hypoparathyroid subjects, and the bearing of these upon the nature of the disorder is debated.

Our thanks are due to the following people who have helped us: To Dr. J. V. Morris for permission to study Case 1, to Dr. T. B. Jones for permission to study Case 2, to Dr. J. C. Rohan for referring Case 3 to our care and for carrying out mental tests on him, to Drs. W. W. Payne and A. I. Cheyne for details of cases discussed in the text, to Dr. M. Israelski for x-ray reports, to Dr. C. Tetlow for electroencephalogram reports, to Dr. S. F. Whittaker for assistance in finding hospital beds for our cases, to Dr. John Sheward for the photograph of Case 3, to Mr. H. Quinton for performing tests of thyroid function on Cases 2 and 3, and to Miss L. O. Morris for help with biochemical estimations.

\section{REFERENCES}

Alexander, S. and Tucker, H. (1949). J. clin. Endocr., 9, 862.

Albright, F., Burnett, C., Parson, W. and Sulkowitch, H. (1941. J. clin. Invest., 20, 445.

$-\frac{1}{922}$. Smith, P. and Parson, W. (1942). Endocrinology, 30, and Ellsworth, R. (1929). J. clin. Invest., 7, 183.

$\longrightarrow$, Forbes, A. and Henneman, P. (1952). Trans. Ass. Amer. Phys., 65, 337.

and Reifenstein, E. (1948). The Parathyroid Glands and Metabolic Bone Disease. Baltimore.

Anderson, I. and Lyall, A. (1939). Quart. J. Med., 8, 209.

Aub, J. (1935). J. Amer. med. Ass., 105, 197.

Azerad, E., Gatha, J. and Raverdy, P. (1953). Bull. Soc. Méd. Hôp. Paris, 69, 199.

Bakwin, H., Gorman, W. and Ziegra, S. (1950). J. Pediat., 36, 567. Barr, D., MacBryde, C. and Sanders, T. (1938). Trans. Ass. Amer. Phys., 53, 227.

Berezin, S. and Stein, J. (1948). J. Pediat., 33, 346.

Berardinelli, W. (1951). Acta endocr., Kbh., 7, 7.

Bille, B. (1952). Acta paediat., Uppsala, 41, 380.

Bishop, P. and Mowbray, R. de (1951). Proc. roy. Soc. Med., 44, 952.

Blohm, R., Wurl, O., Gillespie, J. and Escamilla, R. (1953). J. clin. Endocr., 13, 519.

Brailsford, J. (1945). Brit. J. Radiol., 18, 167.

Brimblecombe, F. (1949). Archives of Disease in Childhood, 24, 77.

Camp, J. (1947). Radiology, 49, 568.

Cantarow, A. (1932). Arch. Pediat., 49, 293.

Stewart, H. and Morgan, D. (1939). Endocrinology, 24, 556

Cantor, M. and Scott, J. (1942). Canad. Ass. med. J., 47, 551. 
Davies, B. and Gordon, A. (1953). Nature, Lond., 171, 1122.

Dent, C. (1953). Proc. roy. Soc. Med., 46, 291.

Drake, T., Albright, F., Bauer, W. and Castleman, B. (1939). Ann. intern. Med., 12, 1751 .

Eaton, L., Camp, J. and Love, J. (1939). Arch. Neurol. Psychiat., Chicago, 41, 921 .

- and Haines, S. (1939). J. Amer. med. Ass., 113, 749.

Ellis, R. and Creveld, S. van (1940). Archives of Disease in Childhood,

15, 65.
Ellsworth, R. and Howard, J. (1934). Bull. Johns Hopk. Hosp., 55, 296.

Elrick, H., Albright, F., Bartter, F., Forbes, A. and Reeves, J. (1950). Acta Endocr., Kbh., 5, 199.

Emerson, K., Walsh, F. and Howard, J. (1941). Ann. intern. Med., $14,1256$.

Franco, S. (1940). Ibid., 14, 529.

Gillam, G. and Morton, F. (1953). Personal communication.

Goerner, A. and Samuelsen, G. (1934). J. Amer. med. Ass., 102, 1001 .

Gotta, H. and Odoriz, J. (1948). J. clin. Endocr., 8, 674.

Grant, D. (1953). Quart. J. Med., 22, 243.

Grant, D. (1953). Quart. S. Med., 22, 243.

Greene, J. and Swanson, L. (1941). Ann. intern.

Himsworth, H. and Maizels, M. (1940). Lancet, 1, 959.

Humphreys, H. (1939). Proc. roy. Soc. Med., 32, 633.

Hunter, D. (1931). Quart. J. Med., 24, 393.

Jordan, A. and Kelsall, A. (1951). Arch. intern. Med., 87, 242.

Kirklin, O. and Childrey, E. (1936). Proc. Mayo Clin., 11, 15.

Lachmann, A. (1941). Acta med. scand., Suppl. 121.

L'Heureux, M., Tepperman, H. and Wilhelmi, A. (1947). J. biol. Chem., 168, 167.

Leonard, M.' (1946). J. clin. Endocr., 6, 493.

Leopold, S. and Jonas, L. (1932). Amer. J. med. Sci., 183, 418.

Levy, H. (1947). Med. Clin. N. Amer., 31, 243.

Liu, S. (1928). J. clin. Invest., 5, 277 .

Lowe, C., Ellinger, A., Wright, W. and Stauffer, H. (1950). J. Pediat, 36, 1.

MacBryde, C. (1938). J. Amer. med. Ass., 111, 304

Martin, E. (1953). Wien. Z. inn. Med., 34, 177.

- and Bourdillon, J. (1940). Rev. méd. Suisse rom., 60, 1166.

-, Guye, P., Babel, J. and Courvoisier, B. (1952). Ann. Endocr., Paris, 13, 943.
McLean, F. (1941), J. Amer. med. Ass, 117, 609

McQuarrie, I., Hansen, A. and Ziegler, M. (1941). J. clin. Endocr.,

Medill, E. (1951). Brit. J. Radiol., 24, 685.

Milne, M. (1951). Clin. Sci., 10,471.

Moehlig, R. and Gerische, R. (1950). J. clin. Endocr., 10, 1609

- and Steinbach, A. (1954). J. Amer. med. Ass., 154, 42.

Morgan, J. (1936). Arch. Path., Chicago, 21, 10.

Morgan, T. (1915). Proc. Soc. exp. Biol., N.Y., 13, 31

Mortell, E. (1946). J. clin. Endocr., 6, 266.

Payne, W. (1953). Personal Communication.

Peterman, M. and Garvey, J. (1949). Pediatrics, 4, 790.

Pope, A. and Aub, J. (1944). New Engl. J. Med., 230, 698.

Reifenstein, E. (1950). In Textbook of Endocrinology, ed. Williams, R. H. Philadelphia.

Reynolds, T., Jacobson, G., Edmondson, H., Martin, H. and Nelson, C. (1952). J. clin. Endocr., 12, 560.

Richardson, J. (1946). Proc. roy. Soc. Med., 39, 514.

Salvesen, H. (1930). Acta med. scand., 73, 511 .

Schüpbach, A. and Courvoisier, B. (1949). Schweiz. med. Wschr., 79, 887.

Scott, E. and Temple, W. (1949). Amer. J. Dis. Child., 77, 758.

Selye, H. (1949). Textbook of Endocrinology, 2nd ed. Montreal

Shelling, D. and Goodman, M. (1934). J. Amer. med. Ass., 102, 669.

Siglin, I., Eaton, L., Camp, J. and Haines, S. (1947). J. clin. Endocr., $7,433$.

Simpson, J. (1952). Brain, 75, 76.

(1954). Brit. J. Derm. Syph., 66, 1.

Simpson, K. (1953). Gt Ormond St.J., 3 (no . 5), 54

Sprague, R., Haines, S. and Power, M. (1945). J. Lab. clin. Med., 30, 363.

Stewart, G. and Bowen, H. (1952). Endocrinology, 51, 80.

Sugar, O. (1953). Arch. Neurol. Psychiat., Chicago, 70, 86.

Sutphin, A., Albright, F. and McCune, D. (1943). J. clin. Endocr. 3, 625 .

Thorpe, E. and Handley, H. (1929). Amer. J. Dis. Child., 38, 328. Uhlemann, H. (1950). Klin. Wschr., 28, 489.

Vero, F., Machacek, G. and Bartlett, F. (1945). J. Amer. med. Ass., $129,728$.

Wise, B. and Hart, J. (1952). Arch. Neurol. Psychiat., Chicago, $68,78$.

\section{AP PENDIX}

\section{Summaries of 23 Cases of Hypoparathyroidism Reported in the Literature Exhibiting Bone Changes, Subcutaneous Calcification or Both}

1. Himsworth and Maizels (1940). English boy of 14 years. Onset of fits aged 5 years. Growth and mentality retarded. Sturdy build. Height $4 \mathrm{ft}$. 5 in., weight $81 \mathrm{lb}$. Red hair. Appeared hypothyroid. Basal metabolic rate $25 \%$. Latent tetany. Cataracts. Bone density normal. Calcified nodules around knee joints. Serum calcium $5 \mathrm{mg}$. per $100 \mathrm{ml}$. No effect from two weeks of parathyroid extract, but response to A.T.10 and Vitamins D2 and D3.

Reported as 'congenital thyroid and parathyroid deficiency'.

2. Lachmann (1941), Case 57. Danish woman of 48 . One of five children, two siblings being Cases 58 and 59 infra. The eldest sister had a cataract operated on at 36 years, was said to be 'queer' mentally, had a haemorrhage of the brain at 50, and died at 53. The youngest sibling, a boy, was normal.

This patient was well throughout her life and had no symptoms. Small and well proportioned. Height $4 \mathrm{ft}$. 5 in., weight $113 \mathrm{lb}$. Thumbs and fourth toes very short. Partial syndactyly toes 2 and 3 . In radiograph, symmetrical under-development of fourth metatarsals. Serum calcium $8.7 \mathrm{mg}$. per $100 \mathrm{ml}$., phosphorus $4.8 \mathrm{mg}$. per $100 \mathrm{ml}$.
3. Lachmann (1941), Case 58. Danish woman aged 39. Sister of cases 57 and 59. 'Poor nerves' always. Scanty, irregular menses. Psoriasis for three years. Small, delicate frame. Height $4 \mathrm{ft} .3 \mathrm{in}$., weight $111 \mathrm{lb}$. Cretinoid appearance. Basal metabolic rate $16 \%$. Intelligence below average. Cataracts. Bones of fifth finger very short, and styloid process of ulna detached in radiographs. Died with exfoliative dermatitis. Serum calcium $8 \cdot 1 \mathrm{mg}$. per $100 \mathrm{ml}$. Necropsy, 'no abnormalities of interest'.

4. Lachmann (1941), Case 59. Danish man aged 40. Tetany on exertion since 19 years old, markedly seasonal. Depression and fatigue. Small, broad-shouldered, with short extremities. Height $4 \mathrm{ft} .10$ in. Cataracts. Cerebral calcification. Metacarpals, metatarsals and phalanges short and plump, especially fourth metacarpals. Styloid process of ulna detached. Serum calcium $6.3 \mathrm{mg}$. per $100 \mathrm{ml}$., phosphorus $5.9 \mathrm{mg}$. per $100 \mathrm{ml}$. Response to A.T.10.

The above three cases reported as 'idiopathic hypoparathyroidism'.

5. Albright, Burnett, Smith and Parson (1942), Case 1. Russian Jewish woman aged 28. Fits from age of 12 . 
Irregular menses. Severely mentally retarded. Round face, short, fat. Height $4 \mathrm{ft} .3 \mathrm{in}$. Index finger longer than middle. Metacarpals and metatarsals short and stubby. Whole skeleton dense. Areas of soft tissue calcification in extremities. Serum calcium $6.4 \mathrm{mg}$. per $100 \mathrm{ml}$. phosphorus $6 \cdot 2 \mathrm{mg}$. per $100 \mathrm{ml}$. Parathyroid hormone $74 \mathrm{ml}$. in 12 days administered with no effect. Response to large doses of A.T.10 (15 mg. daily).

Reported as 'pseudo-hypoparathyroidism'.

6. Albright, Burnett, Smith and Parson (1942), Case 3. American boy aged $3 \frac{1}{4}$ years. Choking spells and wheezing, aged 2 years. Fits from $2 \frac{1}{2}$ years. Obese from infancy. Round faced, stocky. Small, hard, calcified masses to be felt in subcutaneous tissues of trunk and extremities. Bones radiologically normal. Abductor palsy of larynx led to tracheotomy. Serum calcium $7 \cdot 1 \mathrm{mg}$. per $100 \mathrm{ml}$., phosphorus $10 \mathrm{mg}$. per $100 \mathrm{ml}$. Given 1,700 U.S.P. units 'parathormone' in five days without effect. Response to large doses of A.T.10 (20-25 mg.). Laryngeal function returning.

Reported as 'pseudo-hypoparathyroidism'.

7. Sprague, Haines and Power (1945). American woman of 33 years. Convulsions from 14 years. Round face, short, thick set. Agenesis of first, fourth and fifth metacarpals. Intracranial calcification. Calcification of abdominal wall. Serum calcium $4.6 \mathrm{mg}$. per $100 \mathrm{ml}$., phosphorus $5.3 \mathrm{mg}$. per $100 \mathrm{ml}$. No effect from parathyroid hormone in large doses. Response to A.T.10 and calciferol.

Reported as 'pseudo-hypoparathyroidism'.

8. Richardson (1946). English boy aged 16. Fits from $1 \frac{1}{2}$ years. Tetany from age 5 . Short stature. Mental retardation. Rather fat face. Cataracts. Intracranial calcification. Short, squat metacarpals with flecks of soft tissue calcification around them. Serum calcium $4.1 \mathrm{mg}$. per $100 \mathrm{ml}$., phosphorus $9.9 \mathrm{mg}$. per $100 \mathrm{ml}$. Ten days of 'parathormone' 60 units daily failed to control tetany or to influence serum electrolytes. Slow response to calciferol.

Reported as 'chronic idiopathic hypoparathyroidism'.

9. Scott and Temple (1949). American boy of 9 years. Calcified nodules appeared in the skin when aged 2 months. Rapid gain in weight. Grossly obese; weighed $67 \mathrm{lb}$. at 14 months. Convulsions at 5 years. Very backward mentally. Radiograph shows extensive calcification in the skin. Biopsy, bone formation. Serum calcium $7 \cdot 1 \mathrm{mg}$. per $100 \mathrm{ml}$. Serum phosphorus $13 \cdot 1 \mathrm{mg}$. per $100 \mathrm{ml}$.

Reported as 'osteoma cutis', and suggested as a case of pseudo-hypoparathyroidism by Bakwin, Gorman and Ziegra (1950).

10. Peterman and Garvey (1949). American girl of 12. Laryngospasm from infancy. Cramps from 2 years old. Recent fits. Mentally backward. Round face. Height
$4 \mathrm{ft} .6$ in., weight $101 \mathrm{lb}$. Cerebral calcification. Subcutaneous calcification. Generalized osteoporosis. Serum calcium $6 \cdot 6 \mathrm{mg}$. per $100 \mathrm{ml}$., phosphorus $12 \mathrm{mg}$. per $100 \mathrm{ml}$.

Reported as 'pseudo-hypoparathyroidism'.

11. Selye (1949), Case 1. American girl of $8 \frac{1}{2}$ years. Fits. Stocky figure, round face. Peculiar hands; index finger longest, all metacarpals except second shortened. Latent tetany. Interstitial calcification at the wrist. Premature closure of elbow epiphyses and bowing of the radius. Spur formation on the tibia. Serum calcium $4.5 \mathrm{mg}$. per $100 \mathrm{ml}$., phosphorus $10.2 \mathrm{mg}$. per $100 \mathrm{ml}$. Response to A.T.10.

12. Selye (1949), Case 2. Mother of Case 1 supra. 'A mild form of the disease.' Shortening of fingers 4 and 5 , with bowing of the radius. Soft tissue calcification. No tetany or epilepsy. Serum calcium $10.8 \mathrm{mg}$. per $100 \mathrm{ml}$., phosphorus $6.2 \mathrm{mg}$. per $100 \mathrm{ml}$.

The last two cases reported as 'pseudo-hypoparathyroidism'.

13. Schüpbach and Courvoisier (1949). Swiss man of 35 years. Round faced, short. Height $4 \mathrm{ft} .8$ in. Stupid. Mild thyroid enlargement. Short thick fingers. Cataracts. Cerebral calcification. Hyperostosis of skeleton. Short metacarpals. Serum calcium $4.2 \mathrm{mg}$. per $100 \mathrm{ml}$, phosphorus $6.8 \mathrm{mg}$. per $100 \mathrm{ml}$. Response to A.T.10.

Reported as a case intermediate between spontaneous hypoparathyroidism and pseudo-hypoparathyroidism.

14. Gsell (1950). German man of 47 years. Tetany since 8 years. Dwarfism; mild adiposity. Height $4 \mathrm{ft} .8$ in. Slightly retarded mentally. Cataracts. Intracranial calcification. Psoriasis. Skeletal osteoporosis. Short metacarpals. Serum calcium $6 \mathrm{mg}$. per $100 \mathrm{ml}$. Some rise in serum calcium in response to parathyroid hormone.

Reported as 'chronic idiopathic tetany with psoriasis'.

15. Uhlemann (1950), Case 1. German girl aged 20 years. Anxiety attacks and stridor from age of 15 years. Red hair. Dwarfism and adiposity. Height $4 \mathrm{ft} .5 \mathrm{in}$., weight $116 \mathrm{lb}$. Cretinoid appearance. Intelligence at lower limit of normal. Convergent squint. Poorly developed secondary sex characters. Cataracts. Striking shortness of fingers. Metacarpals 4 and 5 and phalanges short. Serum calcium $5.8 \mathrm{mg}$. per $100 \mathrm{ml}$. Response to A.T.10.

16. Uhlemann (1950), Case 2. German girl aged $9 \frac{1}{2}$ years. Sister of Case 1 supra. Height $4 \mathrm{ft}$. 2 in., weight $44 \mathrm{lb}$. Short plump fingers. Metacarpals 2 to 5 short and plump, with premature fusion of epiphyses. Terminal phalanges broad. Serum calcium $7.8 \mathrm{mg}$. per $100 \mathrm{ml}$. Response to A.T.10.

Both the above cases reported as 'familial idiopathic tetany'. 
17. Elrick, Albright, Bartter, Forbes and Reeves (1950), Case 2. Italian girl aged 17 years. Main complaint of excessive sleepiness. Obesity and short stature. Height $4 \mathrm{ft} .3$ in., weight $146 \mathrm{lb}$. Mentally retarded. Short fingers and toes; index as long as middle finger. Multiple areas of soft tissue calcification. Serum calcium $6 \mathrm{mg}$. per $100 \mathrm{ml}$., phosphorus $6 \mathrm{mg}$. per $100 \mathrm{ml}$.

Reported as 'pseudo-hypoparathyroidism'.

18. Alexander and Tucker (1950). American man aged 49 years; married with two normal children. Fat from infancy. Short, stocky. Height $4 \mathrm{ft}$. 11 in., weight $145 \mathrm{lb}$. Limbs short relative to trunk. Cataracts. Parkinsonism. Intracranial calcification. Subcutaneous plaques of bone, with limitation of movement at many joints. Serum calcium $6.8 \mathrm{mg}$. per $100 \mathrm{ml}$., phosphorus $4.5 \mathrm{mg}$. per $100 \mathrm{ml}$. Response to A.T.10.

Reported as 'pseudo-hypoparathyroidism'.

19. Bakwin, Gorman and Ziegra (1950). American girl aged 16 years. Diagnosed aged 8 as chondrodystrophy. Convulsions from age 14. Short, with short arms. Height $4 \mathrm{ft} .2$ in. Short fingers of irregular length, asymmetrical on the two sides. Mentality lower limit of normal. Metacarpals short and broad, except right second and left third. Phalanges of feet abnormal. Ulnae and radii broad and gnarled; fibulae bent. Serum calcium $6.7 \mathrm{mg}$. per $100 \mathrm{ml}$., phosphorus $7.0 \mathrm{mg}$. per $100 \mathrm{ml}$. Response to both A.T.10 and 'calciferol'.

Reported as 'pseudo-hypoparathyroid tetany'.

20. Bishop and de Mowbray (1951). English girl of 18 years. Tetany from 6 years old. Always under-sized. Round faced, dwarfed, somewhat obese. Height $4 \mathrm{ft}$. 7 in., weight $102 \mathrm{lb}$. Short hands. Shortening of fourth and fifth metacarpals and of fourth metatarsals, and terminal phalanges of fingers. Marked mental retardation. Intracranial calcification. Soft tissue calcification. Bowing of tibiae, with osteophyte formation. Serum calcium $6 \mathrm{mg}$. per $100 \mathrm{ml}$., phosphorus $4.2 \mathrm{mg}$. per $100 \mathrm{ml}$. Response to A.T.10.

Reported as 'pseudo-hypoparathyroidism'.

21. Reynolds, Jacobson, Edmondson, Martin and Nelson (1952). American negro male aged 29 years. Mental retardation from childhood. Fits from age 8. Cataracts from 8 years. Subcutaneous nodules from 10 years. Short, well proportioned. Height $5 \mathrm{ft}$., weight $116 \mathrm{lb}$. Round face. Early Parkinsonism. Calcification of basal ganglia. Generalized demineralization of skeleton. Metacarpals and phalanges short and thick, chiefly fifth metacarpals. Flattening of femoral heads. Serum calcium $5.8 \mathrm{mg}$. per $100 \mathrm{ml}$., phosphorus $5.4 \mathrm{mg}$. per $100 \mathrm{ml}$. Response to A.T.10.

Reported as 'pseudo-hypoparathyroidism'.

22. Bille (1952). Swedish girl of 9 years. Obesity and short stature from early infancy. Convulsions from 7 years old. An uncle was an imbecile of similar physique, but with normal serum calcium. Short (4 ft. 1 in.), thick-set, round face. Index finger longer than the others. Intelligence quotient 71 . Shortness of all metacarpals except second. Subcutaneous calcification around ankle. Serum calcium $6 \mathrm{mg}$. per $100 \mathrm{ml}$., phosphorus $12.5 \mathrm{mg}$. per $100 \mathrm{ml}$. Ellsworth-Howard test (intramuscular 'paroidin' 200 units) negative. Some inconstant rise in serum calcium in response to several injections of parathyroid hormone. Trial of A.T.10 in small ( $5 \mathrm{mg}$.) doses produced little effect.

23. Azerad, Gatha and Raverdy (1953). French woman, aged 24. Always obese. Fits from 7 years old. Sister had fits and cataracts, and died at 20 years in an unexplained coma. At 7 years early papilloedema was noticed, and an accompanying loss of vision appeared to be accentuated by a course of arsenical treatment. Soon after cataracts appeared, and in the early 20s acute glaucoma necessitated enucleation of the left eye. The same condition then appeared on the right. Short (4 ft. 3 in.), stumpy build with a round face. Short extremities. Index finger longer than the others. Subcutaneous calcification of face. Teeth irregularly erupted and spaced. Mentality childish; very dependent on her mother. Basal metabolic rate $20 \%$. Radio-active iodine uptake normal. Serum calcium $8.6 \mathrm{mg}$. per $100 \mathrm{ml}$., phosphorus $5.5 \mathrm{mg}$. per $100 \mathrm{ml}$. Radiographs of bone show marked general decalcification. Ellsworth-Howard test negative.

For details of the following unpublished case of pseudo-hypoparathyroidism we are indebted to Dr. W. W. Payne.

English boy aged 7 years. At 6 months old calcified lumps in the skin began to appear and were distributed widely over the body. Biopsy of one of these revealed ectopic bone. Stout infant, backward in speaking, Undescended testicles. Serum calcium $6.3 \mathrm{mg}$. per $100 \mathrm{ml}$., phosphorus $7 \cdot 2 \mathrm{mg}$. per $100 \mathrm{ml}$. At $6 \frac{1}{2}$ years, weight $37 \mathrm{lb}$., height $3 \mathrm{ft} .8$ in. Intelligence quotient 60 . Some response was observed to 'parathormone' 40 U.S.P. units intravenously, notably a twofold increase in urinary phosphorus excretion between the sixth and ninth hours after injection. Good therapeutic response to calciferol.

For details of the following case of steatorrhoea, which is referred to in the text, we are indebted to Dr. A. I. Cheyne.

Man aged 30. Well until nine months before admission, when paraesthesiae in hands, transitory oedema of the ankles and weakness developed, but lasted only a short time. Some months later he developed carpo-pedal spasms and on examination was found to have latent tetany. He was otherwise in vigorous health, and nothing to account for his tetany was found in his past history, in his urine, or in bone radiographs, but a three-day stool analysis showed a fat excretion of $11 \mathrm{~g}$. per day. His serum values for calcium and phosphorus were $6 \cdot 2$ and $6.3 \mathrm{mg}$. per $100 \mathrm{ml}$. respectively. An Ellsworth-Howard test gave a negative result. After four days of 150 U.S.P. units 'parathormone' daily serum calcium and phosphorus values were, respectively, 6.0 and $5.0 \mathrm{mg}$. per $100 \mathrm{ml}$. 